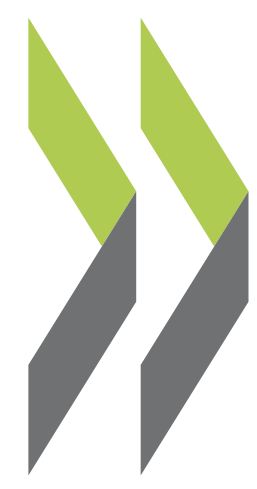

OECD Social, Employment and Migration Working Papers No. 104

\title{
Israeli Child Policy and Outcomes
}

\section{John Gal,}

Mimi Ajzenstadt,

Asher Ben-Arieh, Roni Holler,

Nadine Zielinsky 
Organisation de Coopération et de Développement Économiques

Organisation for Economic Co-operation and Development

18-Mar-2010

DIRECTORATE FOR EMPLOYMENT, LABOUR AND SOCIAL AFFAIRS

English - Or. English

EMPLOYMENT, LABOUR AND SOCIAL AFFAIRS COMMITTEE

OECD SOCIAL, EMPLOYMENT AND MIGRATION WORKING PAPERS NO. 104

ISRAELI CHILD POLICY AND OUTCOMES

by John Gal, Mimi Ajzenstadt, Asher Ben-Arieh, Roni Holler, Nadine Zielinsky

JEL Classification: $H 2, H 3, H 4, H 5, I 2, I 3, J 1$

Keywords: Israel, social policy, child policy, education, health work and labour reconciliation

All Social, Employment and Migration Working Papers are now available through OECD's Internet website at http://www.oecd.org/els

JT03280340

Document complet disponible sur OLIS dans son format d'origine

Complete document available on OLIS in its original format 


\title{
DIRECTORATE FOR EMPLOYMENT, LABOUR AND SOCIAL AFFAIRS
}

www.oecd.org/els

\section{OECD SOCIAL, EMPLOYMENT AND MIGRATION WORKING PAPERS}

\author{
www.oecd.org/els/workingpapers
}

This series is designed to make available to a wider readership selected labour market, social policy and migration studies prepared for use within the OECD. Authorship is usually collective, but principal writers are named. The papers are generally available only in their original language - English or French - with a summary in the other.

Comment on the series is welcome, and should be sent to the Directorate for Employment, Labour and Social Affairs, 2, rue André-Pascal, 75775 PARIS CEDEX 16, France.

The opinions expressed and arguments employed here are the responsibility of the author(s) and do not necessarily reflect those of the OECD.

Applications for permission to reproduce or translate all or part of this material should be made to:

\author{
Head of Publications Service \\ OECD \\ 2, rue André-Pascal \\ 75775 Paris, CEDEX 16 \\ France
}

Copyright OECD 2009 


\section{EXECUTIVE SUMMARY}

This report presents an overview of child policy in Israel. It covers a wide range of services and policies that are intended to further the wellbeing of children in Israel or that have an impact upon the wellbeing of children, including the fields of education, health, cash transfers, taxation and personal social services. In addition, the labour market and policies linked to work and family reconciliation are discussed. The report also offers a brief overview of the context in which these policies and services developed, and their consequences, with a special emphasis on child poverty. This is due to the unusually high level of poverty among children in Israel. The report concludes with a discussion of the factors that have an impact upon the degree of effectiveness of child policies in Israel or, in the case of child poverty, upon their limited effectiveness. This discussion is followed by a number of policy recommendations intended to help policies and services to improve children's wellbeing in Israeli society.

\section{RÉSUMÉ}

Ce rapport présente un aperçu des politiques de l'enfant en Israël. Il couvre une large gamme de services et de politiques qui sont destinées à augmenter ou à influencer le bien-être des enfants en Israël, aussi bien dans les domaines éducatifs, de la santé, des transferts d'argent, des impôts et des services sociaux destinés aux personnes. Le rapport discute en outre les politiques visant à réconcilier le travail et la vie de famille. Il offre aussi un bref aperçu du contexte dans lequel ces politiques et services se sont développés et leurs conséquences, en mettant en particulier l'accent sur la pauvreté des enfants qui atteint un niveau exceptionnel dans le pays. Le rapport se termine par une discussion des facteurs qui influent sur l'efficacité des politiques destinés aux enfants en Israël ou, dans le cas de la pauvreté des enfants, sur leur efficacité limitée. Un certain nombre de recommandations suivent sur les politiques et les services destinés à améliorer le bien-être des enfants dans la société israélienne. 
The OECD Council decided to open accession discussions with Israel on 16 May 2007, and an Accession Roadmap, setting out the terms, conditions, and process for Accession was adopted on 30 November 2007 (see www.oecd.org search for "OECD Enlargement"). The OECD's Employment, Labour and Social Affairs Committee was requested to review Israel's labour Market and Social Polices and, as part of this process, prepared the OECD Review of Labour Market and Social Policies in Israel which was released in January 2010 (www.oecd.org/els/israel2010).

This publication covered a wide range of issues including: improving enforcement of labour laws; investing more in effective ALMPs, including welfare-to-work policies; strengthening the fight against discrimination; extending infrastructural investment in Arab localities; extending coverage of pension saving; new policies on foreign workers with temporary permits; and, policies to help absorb large quantities of permanent migrants.

The present paper was commissioned from John Gal, Mimi Ajzenstadt, Asher Ben-Arieh, Roni Holler and Nadine Zielinsky, acting as consultants to the OECD Secretariat in order to provide background information for the OECD review, but is not part of it. The views expressed in this paper cannot be attributed to the OECD or its Members; they are the responsibility of the authors alone.

Le Conseil de l'OCDE a décidé d'ouvrir des discussions avec Israël le 16 mai 2007 et une feuille de route, adoptée le 30 novembre 2007, définit les modalités, les conditions et le processus devant permettre à Israël d'adhérer à l'OCDE (voir www.oecd.org, recherchez sous "l'élargissement et l'engagement renforcée"). Le Comité de l'emploi, du travail et des affaires sociales de l'OCDE a été mandaté pour passer en revue le marché du travail et les politiques sociales d'Israël et, dans le cadre de ce processus, a préparé "l'examen des politiques sociales et du marché du travail d'Israël " qui a été publié en janvier 2010 (www.oecd.org/els/israel2010- en anglais seulement).

Cette publication couvre une vaste gamme de questions, notamment : améliorer l'application du droit du travail ; investir davantage dans des politiques actives du marché du travail qui soient plus efficaces et en particulier dans les mesures de réinsertion ; renforcer la lutte contre la discrimination ; accroître les investissements en infrastructures dans les localités arabes ; étendre la couverture du régime de retraite ; mettre en place un nouveau régime de permis temporaires pour les travailleurs étrangers et prendre des initiatives pour faciliter l'absorption d'un grand nombre de migrants permanents.

Ce rapport a été rédigé par John Gal, Mimi Ajzenstadt, Asher Ben-Arieh, Roni Holler et Nadine Zielinsky, consultants au Secrétariat de l'OCDE, pour fournir les informations de base en vue de l'examen de l'OCDE, dont il ne fait pas toutefois partie intégrante. Les points de vue exprimés dans ce document ne peuvent être attribués à l'OCDE ou à ses membres ; ils sont de la responsabilité des seuls auteurs. 


\section{TABLE OF CONTENTS}

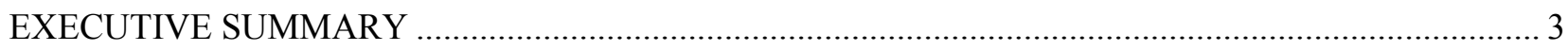

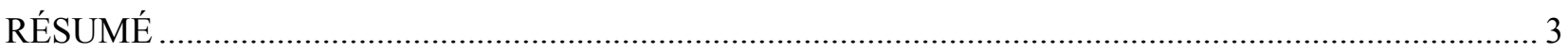

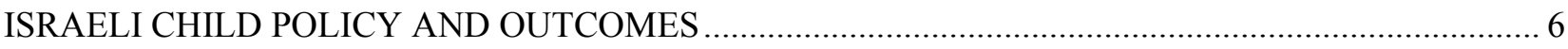

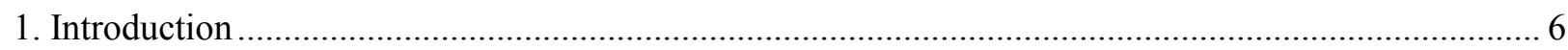

2. The Israeli Welfare State - A Brief Overview ……........................................................................ 7

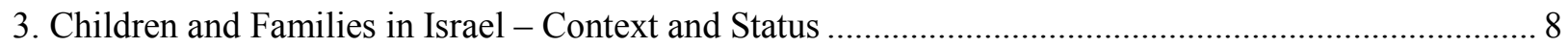

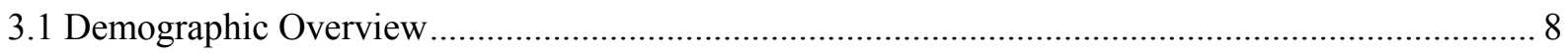

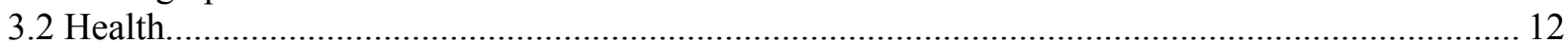

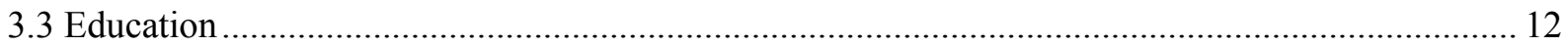

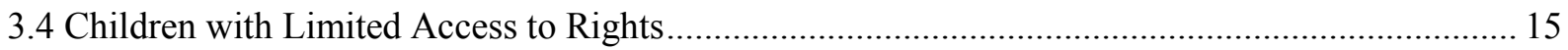

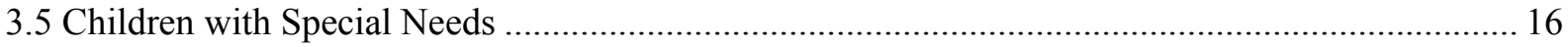

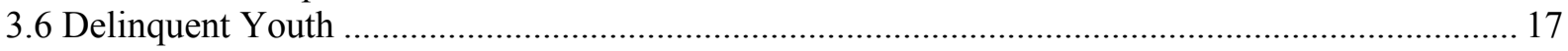

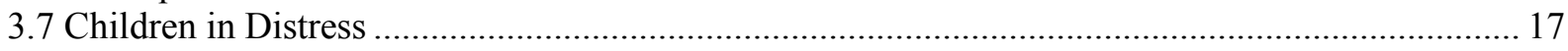

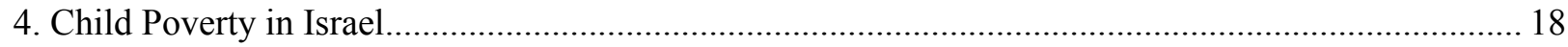

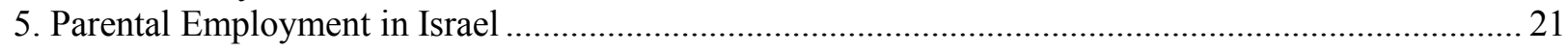

6. Support for Families and Children in the Benefit and Tax Systems ……......................................... 23

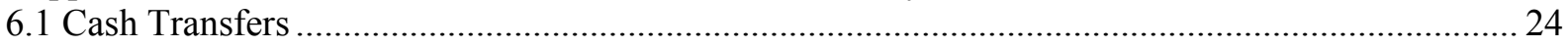

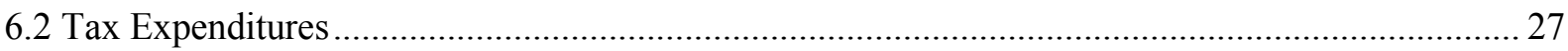

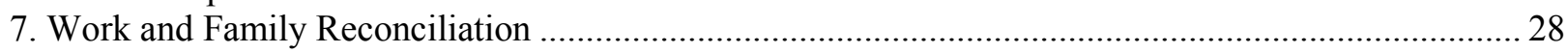

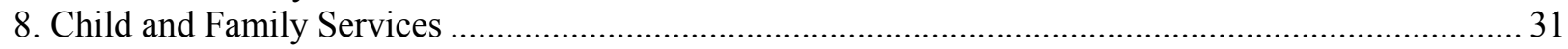

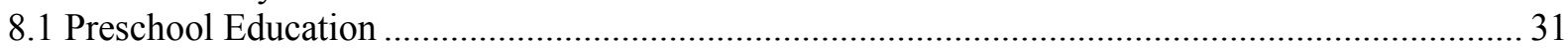

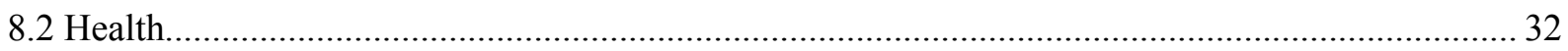

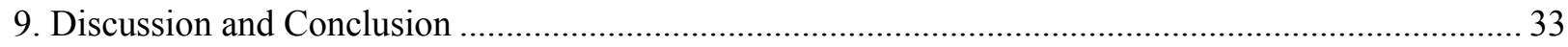

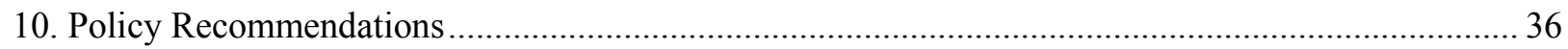

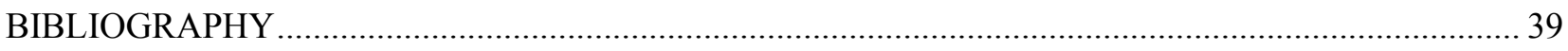

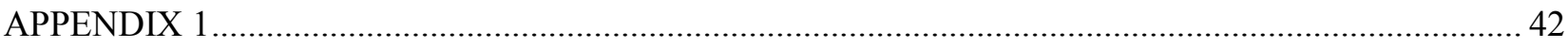

\section{Tables}

Table 3.1. Children in Families*, by Type of Family, Number of Children and Population.................... 10

Table 3.2. The Share of Single-Parent Families* in all Families (Percentages) ...................................... 11

Table 3.3. Rate of Enrollment in the Education system (percentages), by age and sectors, 2007/8

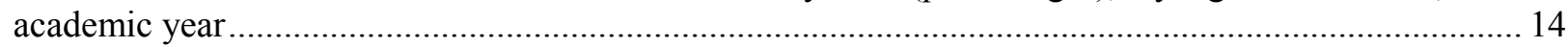

Table 4.1 Relative Poverty Rates (50\%) among Children in Various Welfare States (percentages)........ 19

Table 6.1 National Insurance Institute Benefit Payments, 2008 (\% of all payments).............................. 27

Table 7.1 Child Care Cost*, after subsidies (percentage of the APW) ${ }^{* *}$............................................... 30

\section{Figures}

Figure 4.1 Poverty Prevalence among children (percentages), across years*....................................... 20

Figure 6.1 Proportion of National Insurance Institute Expenditure on Benefits ...................................... 24 


\section{ISRAELI CHILD POLICY AND OUTCOMES}

\section{Introduction}

1. Child policy is an integral and often central component of the social policy of any welfare state. This is particularly the case in a nation, such as Israel, in which inhabitants under the age of 18 comprise a third of the population. This report seeks to provide the reader with a comprehensive overview of child policy in Israel. We start with a brief description of the context of the report. We then provide a brief overview of the Israeli welfare state, describing its development and explaining its structure and guiding principles. Here we have also included cross-national data that provide some key comparative indicators on various issues.

2. The third section discusses the status of children and families in Israel in light of a series of both context and outcome indicators, with a specific emphasis on aspects of children's wellbeing. Whenever possible, the data is presented separately for the various population groups in Israel. Section four focuses on child poverty, including how poverty is defined as well as an overview of child poverty in the country.

3. We then turn to parental employment and present data on the levels and nature of the employment and incomes of households with children in Israel. This data is presented (whenever possible) by family size, population group and gender. The parental employment data is followed by an overview of the transfer payment and tax expenditure systems directed at families with children. Here we focus on child benefits and other cash transfers provided by the social security system, and reference their development in recent years. Expenditure levels on cash transfers for children and families as a proportion of overall spending and their evolution over time are provided. In addition, this section of the report discusses the way in which the tax system deals with families with children, in particular tax expenditures.

4. Section seven sheds light on work-family reconciliation issues. Various aspects of the Israeli welfare state that contribute to work and family reconciliation are discussed, including protective legislation, cash transfers and in-kind services. As for the latter, data on the existing early childhood education and care system are provided. The system's structure and regulatory system are discussed, as well as their implications for families.

5. Additional child and family services are discussed in section eight, in particular those in the education and health sectors as well as local personal social services. In addition, this section discusses the growing role of non-state organisations in the provision and funding of services for children and families in various sectors of the population.

6. Section nine focuses on the factors that explain differences in outcomes for children. It draws together the findings and discussions of various issues presented in previous sections. Whenever possible, the data presented draw upon the findings of comparative studies undertaken by Israeli scholars. Finally, section ten identifies directions for more effective child policies in Israel, and makes recommendations for policy possibilities in specific fields of child policy. 


\section{The Israeli Welfare State - A Brief Overview}

7. Welfare and social security institutions existed in Palestine prior to the establishment of the State of Israel in 1948. Up until the second half of the nineteenth century, traditional religious institutions provided rudimentary services in the country. Following the formation of the British Mandate in Palestine in 1921, a number of different institutions developed. Some were established directly by the British Mandatory authorities, particularly in the fields of correction and labour regulation. Others were established by non-state organisations in both the Jewish and Arab Palestinian communities, including health, education and welfare services of diverse types and quality. A primary force in the formulation of welfare and social security services was the Histadrut, the Jewish trade union federation. Many of these institutions continued to function, often as part of the newly formed state, after Israel was established (for overviews of the historical development of the Israeli welfare state, see Doron \& Kramer, 1991; Gal \& Bargal, 2002).

8. The contemporary Israeli welfare state is comprehensive and combines an adherence to the Beveridge social insurance model with an emphasis on social assistance to the poor. Benefit levels are relatively low. In addition, as is the case in liberal welfare states, Israel places great emphasis on the voluntary market provision of social protection, particularly through the widespread existence of occupational retirement pensions, with state programs intended to serve as safety net and top-up. Noncontributory universal benefits have, historically, played a major role in the Israeli welfare state. The National Insurance Institute (NII), the state social security agency, and other government offices offer benefits that cover most contingencies and social risks. These include child benefits and unemployment insurance supplemented by means-tested social assistance. Alongside these, Israel has a national health service that, since 1996, has provided universal access to health care through four non-state providers and state-run hospitals.

9. While the Israeli welfare state was clearly based on the British Beveridge model when it was first established in the 1950s, it moved closer to the social-democratic model in the 1970s, with the introduction of more wage-related benefits, wider coverage of needs and better indexing of benefit levels. Nevertheless, during recent decades the Israeli welfare state has seen some marked trends towards the privatisation of social services, greater dependency on market provision, more limited access to some benefit programs, and attempts to introduce more selectivity into the social security and welfare systems, through the use of income-testing (for an overview of these trends, see Doron, 2001).

10. Indeed, over the last decade, the welfare state in Israel has been characterised by cuts in spending levels and the devolution of welfare provision both from the national level to the local level and from state to non-profit and for-profit private providers. Consequently, cash transfers for children and families were cut significantly during the initial years of the current decade. At the same time, there were major cuts in state expenditure devoted to services for children in need. Moreover, privatisation has led to the outsourcing of services in diverse fields and to an increasing dependence on third sector and charity organisations among the needy. Yet despite these changes, the state still plays a major role in the provision of social services at large and in particular those services intended for young children.

11. In 2007, state spending on social services (inclusive of education) was 105.4 billion New Israeli Shekels (NIS), and it was budgeted to rise in 2008 to 111.6 billion NIS. The share of social spending in the 2007 and 2008 state budgets was 50.9\% and 50.7\%, respectively (not including debt servicing). After a period of significant cuts in social spending in the first years of this decade, social expenditure rose over the last three years. Indeed, the current spending level is similar to the relatively high level of spending in 2001, prior to the economic downturn of the 2002-2004 period. Nevertheless, when taking into account population growth, social spending levels per capita have in fact dropped from a peak of 18000 NIS per capita in 2000 to 14000 to 15000 NIS per capita in recent years (Horev \& Kop, 2009). When viewed in a 
cross-national comparative perspective employing OECD social protection definitions, it emerges that public expenditure on social protection is relatively low - 16\% of GDP in 2006 (National Insurance Institute [NII], 2008a).

12. State social spending includes in-kind services, transfer payments and tax expenditures. In 2008, in-kind services, primarily health and education, comprised $60.9 \%$ of all direct social spending, while the remainder was devoted to transfer payments, mainly those provided by the NII. Of funding for in-kind services, just over half was devoted to education, $26.6 \%$ to health, $10.1 \%$ to personal social services and the remainder to other social services (labour, immigration absorption, etc.) (Horev \& Kop, 2009). With regard to indirect social spending, in 2009 tax advantages targeting families with children were projected to comprise a total of 2110 million NIS, or $5.4 \%$ of all tax expenditures (Ministry of Finance, State Revenues Administration, 2008).

13. In conclusion, the Israeli welfare state is a relatively comprehensive welfare state in an advanced market economy. However, overall levels of social spending are not high and are similar to those in liberal welfare states. While covering a wide range of social risks and needs, the Israeli welfare state has tended to offer relatively ungenerous benefits and services. Moreover, market-oriented reforms in various domains of social protection and attempts to cut spending levels and to reduce access to benefits and service have led to lower levels of per capita spending in recent years. This is particularly the case for families with children, and can partly explain the particularly high levels of child poverty in Israel, particularly those among the Arab and ultra-orthodox Jewish populations.

\section{Children and Families in Israel - Context and Status}

\subsection{Demographic Overview ${ }^{1}$}

14. At the end of 2008, the number of children living in Israel totalled 2453100 , constituting $33 \%$ of the general population (Tzionit, Berman \& Ben-Arieh, 2009). Thus, children comprise a much larger share of the overall population than in most welfare states, yet the proportion remains lower than the equivalent percentage in Israel's neighbouring countries. Accordingly, in Israel the 0-17 age group remains the base of the age pyramid, unlike the case in many industrialised countries where it has reversed in recent years.

15. Despite the large share of children and in spite of the fact that the absolute number of children has grown since the mid-1990s, the percentage of children in the total population has steadily decreased. More specifically, while $34.8 \%$ of the total population were children in 1995 (ages 0-17), in 2008 their share was $33 \%$. ${ }^{2}$ Breaking down by religious group, the percentage of children is as follows: Jews $30.4 \%$; Muslim 48\%; Christian 28.9\%; Druze 38\%; and unclassified religion 24.8\%. Among all groups, religious families generally have more children than secular families (Tzionit, et al., 2009). With regard to geographical differences, in the peripheral areas in the north and south of Israel, the percentage of children in relation to the overall population is high, whereas in the central area of Israel and along the northern coastal plain, the percentage is relatively low. This data apparently indicates a clear connection between the socio-economic status of a locality and the number of children living in it.

\footnotetext{
${ }^{1}$ The data in this section and in the following sections draw upon that provided in Tzionit, Kimchi \& Ben-Arieh, 2008, unless otherwise stated.

${ }^{2}$ It is important to note that the decrease slowed to a halt in 2004 as a result of the growing number of families with three or more children and the falling number of families with a single child.

${ }^{3}$ Children of unclassified religion refers to children whose parents prefer not to fill in the religion clause on their IDs. These are mostly immigrant children from the Former Soviet Union (FSU).
} 
16. The Israeli total fertility rate was 2.96 children per woman in 2008 . Broken down by religion, the fertility rate among Jews reached 2.88, among Muslims 3.84, Christians 2.11, Druze 2.49 and others 1.57. The average age of mothers at first birth was almost 27. The Muslim population differed significantly with the first birth at 23.3 years (Central Bureau of Statistics [CBS], 2009b).

17. It is important to note that the Jewish demographic data obscures major differences between the ultra-orthodox community and the rest of the Jewish population. Although formal and reliable data is lacking, according to a recent study conducted by the Central Bureau of Statistics (Gurovich \& CohenKastro, 2004) the total fertility rate of the ultra-orthodox community was 7.7 , compared to 2.6 among the total Jewish population. ${ }^{4}$

18. Israel's child population is far from homogenous. It is comprised of nearly $69.2 \%$ Jews, 24.2\% Muslims, $1.8 \%$ Christians, $1.9 \%$ Druze and 2.9\% of unclassified religion. As for age differences, the older the children in Israel, the lower their numbers (from 153600 aged birth to one year, to 116800 aged 17). A rural-urban divide indicates that that most of the children in Israel live in urban localities (91\%), and only nearly $9 \%$ live in rural localities (2000 residents or less). The portion of Jewish children living in rural localities is lower than that of other religious groups (Tzionit, et al., 2009).

19. The share of immigrant children in the general population of Israeli children is among the highest in the Western countries. Since its establishment, the State of Israel has absorbed numerous children, most of whom were Jewish. The numbers of non-Jewish children entering Israel have been increasing, especially in recent years. In the past decade, most immigrant children have arrived from Ethiopia and the former Soviet Union, but many have also arrived from Western countries, especially France, the United States, and Argentina. Recent data shows that there are 235000 children of immigrants in Israel, of whom nearly $40 \%$ are children who immigrated by themselves (Tzionit, et al., 2009).

20. In Israel there are almost one million families with children, $33 \%$ of which have one child, $30.9 \%$ have two children, $19.1 \%$ have 3 children, $8.6 \%$ have 4 children, $4 \%$ have 5 and $4.4 \%$ have 6 or more. Data on families with children in the various population groups is presented in Table 3.1 below.

\footnotetext{
${ }^{4}$ Data refers to 2001.
} 
Table 3.1. Children in Families*, by Type of Family, Number of Children and Population

Group (Thousands and Percentages), 2005

\begin{tabular}{|c|c|c|c|c|c|c|}
\hline \multirow{2}{*}{$\begin{array}{l}\text { Type of Family and } \\
\text { Population Groups }\end{array}$} & \multirow[t]{2}{*}{ Total } & \multicolumn{4}{|c|}{ Number of Children Ages 0-17 in the Family } & \multirow{2}{*}{$\begin{array}{l}\text { Average No. of } \\
\text { children in } \\
\text { Family }\end{array}$} \\
\hline & & 1 & 2 & 3 & 4 & \\
\hline \multicolumn{7}{|c|}{ Thousands } \\
\hline Total** & $2,174.8$ & 311.2 & 589.2 & 529.6 & 744.7 & 2.3 \\
\hline $\begin{array}{c}\text { Couple with children } \\
\text { up to age } 17\end{array}$ & $2,010.0$ & 256.4 & 532.7 & 502.2 & 718.8 & 2.4 \\
\hline Total- Jews** & $1,552.4$ & 258.9 & 482.9 & 391.9 & 418.7 & 2.2 \\
\hline $\begin{array}{l}\text { Of which: Couple } \\
\text { with children up to } \\
\text { age } 17\end{array}$ & $1,416.3$ & 211.4 & 433.5 & 370 & 401.4 & 2.3 \\
\hline $\begin{array}{l}\text { Single parent with } \\
\text { children up to age } 17\end{array}$ & 135.3 & 46.9 & 49.4 & 21.9 & 17.1 & 1.6 \\
\hline Total-Arabs** & 586.8 & 37.9 & 91.7 & 133.2 & 323.9 & 3 \\
\hline $\begin{array}{l}\text { Of which: Couple } \\
\text { with children up to } \\
\text { age } 17\end{array}$ & 565.7 & 34.7 & 87.5 & 128.1 & 315.4 & 3.1 \\
\hline $\begin{array}{l}\text { Single parent with } \\
\text { children up to age } 17\end{array}$ & 20.9 & 3.2 & 4 & 5.1 & 8.5 & 2.4 \\
\hline Total-Others** & 35.6 & 14.4 & 14.7 & 4.6 & -2 & 1.5 \\
\hline $\begin{array}{l}\text { Of which: Couple } \\
\text { with children up to } \\
\text { age } 17\end{array}$ & 28.1 & 10.2 & 11.6 & 4.2 & -2 & 1.6 \\
\hline $\begin{array}{c}\text { Single parent with } \\
\text { children up to age } 17\end{array}$ & 7.4 & 4.1 & 3 &.. & - & 1.3 \\
\hline \multicolumn{7}{|c|}{ Percentage } \\
\hline Total ${ }^{* *}$ & 100 & 14.3 & 27.1 & 24.4 & 34.2 & - \\
\hline $\begin{array}{l}\text { Of which: Couple } \\
\text { with children up to } \\
\text { age } 17\end{array}$ & 100 & 12.8 & 26.5 & 25 & 35.8 & - \\
\hline $\begin{array}{l}\text { Single parent with } \\
\text { children up to age } 17\end{array}$ & 100 & 33.1 & 34.5 & 16.8 & 15.7 & - \\
\hline Total- Jews** & 100 & 16.7 & 31.1 & 25.2 & 27 & - \\
\hline $\begin{array}{l}\text { Of which: Couple } \\
\text { with children up to } \\
\text { age } 17\end{array}$ & 100 & 14.9 & 30.6 & 26.1 & 28.3 & - \\
\hline $\begin{array}{l}\text { Single Parent with } \\
\text { children up to age } 17\end{array}$ & 100 & 34.7 & 36.5 & 16.2 & 12.6 & - \\
\hline Total-Arabs** & 100 & 6.5 & 15.6 & 22.7 & 55.2 & - \\
\hline $\begin{array}{c}\text { Of which: Couple } \\
\text { with children up to } \\
\text { age } 17\end{array}$ & 100 & 6.1 & 15.5 & 22.6 & 55.8 & - \\
\hline $\begin{array}{l}\text { Single parent with } \\
\text { children up to age } 17\end{array}$ & 100 & 15.3 & 19.2 & 24.5 & 41 & - \\
\hline Total-Others** & 100 & 40.4 & 41.4 & 12.8 & -5.7 & - \\
\hline $\begin{array}{l}\text { Of which: Couple } \\
\text { with children up to } \\
\text { age } 17\end{array}$ & 100 & 36.4 & 41.5 & 15 & -7.2 & - \\
\hline $\begin{array}{l}\text { Single parent with } \\
\text { children up to age } 17\end{array}$ & 100 & 54.5 & 40.4 & .. & - & - \\
\hline
\end{tabular}

* Families wherein children live with at least one parent or one grandparent.

** Including a family without parents but with a grandparent and grandchildren ages 15-17.

Note: The data does not include families living in institutions, kibbutz, student dorms or outside localities.

Source: Tzionit, et al., 2008

21. According to the table, in 2005 nearly two-thirds of the children lived in families with one to three children. $34.2 \%$ of the children lived in families with four or more children, which make up 
approximately $17 \%$ of the total number of families. Breaking down the data by population group, it emerges that more than half of the Arab children (approximately 55\%) live in families of four or more children, in comparison to $27 \%$ of Jewish children in families of that size. Furthermore, the average number of children per family in 2005 was 3.0 in Arab families, and 2.2 in Jewish families, and approximately 1.5 in parentless families (a grandparent and grandchildren aged 15-17).

22. Although most children in Israel live with both of their parents, since the early 1990s there has been a marked increase in the number of children living in single-parent households. In 2005, more than 200,000 children, comprising $9.0 \%$ of the total child population, lived in single-parent households. Of these, nearly $69 \%$ were children of divorced parents, nearly $14 \%$ were orphans, and $18 \%$ were children of unmarried mothers. In the majority of single-parent households (approximately $70 \%$ ), there were one or two children. One child was the most frequent in families with a single unmarried parent (48.5\%). Three or more children lived in single-parent households headed by a widowed parent $(43.9 \%)$ relatively more than they do in single-parent households headed by a divorced parent $(31 \%)$ or an unmarried parent $(18.6 \%)$. Furthermore, in 2006 the percentage of single-parent households among immigrant families (27.4\%) was almost three times higher than the percentage of single-parent households among non-immigrant families $(10.2 \%){ }^{5}$ Nevertheless, and in spite of the recent increase, when compared with other welfare states, the proportion of single-parent families in Israel is relatively small (as can be seen in Table 3.2).

Table 3.2. The Share of Single-Parent Families* in all Families (Percentages)

\begin{tabular}{|l|c|}
\hline Country & $\begin{array}{c}\text { Share of single- } \\
\text { parent families }\end{array}$ \\
\cline { 2 - 2 } Canada & 10 \\
Germany & 16 \\
Greece & 5 \\
\hline Israel & 6 \\
\hline Italy & 6 \\
\hline Netherlands & 13 \\
\hline Norway & 10 \\
Spain & 6 \\
\hline USA & 16 \\
\hline
\end{tabular}

23. Finally, marriage among minors is a marginal phenomenon in Israel. According to official records for 2005, 237 girls aged 16 or younger were married, and nearly 1440 girls and 40 boys aged 17 were married. As evident from the data, young brides are far more common than young grooms, who are a rare phenomenon. The marriage of minors under the age of 17 is far more common among Muslims than among members of other religions. The data also show a decrease in the number of births by minors of every religion.

\footnotetext{
${ }^{5}$ Data refers to the Jewish population.
} 


\subsection{Health}

24. The life expectancy of children born in recent years has increased over the years for both genders and for Jews and non-Jews. However, there is still a small but constant gap in life expectancy between the two populations, in favour of Jews and in favour of girls. The life expectancy for female Jews is 82.4 years; for male Jews 78.7; female Arabs 78.5 and male Arabs 74.9. Despite these gaps, compared to other European region countries, the life expectancy of children in Israel is still high, both among males and females. ${ }^{6}$

25. Mortality among infants and children has drastically decreased in all population groups since the early 1970s, but most prominently among the Arab population groups: Muslims, Christians and Druze. Nevertheless, infant mortality rates among Muslim and Druze newborns remain twice as high as among Christians and Jews. The total infant mortality rate is currently (2006) 3.9 deaths per 1000 live births, as compared to 23.5 in 1970 . Broken down by religious groups, the rate has decreased since 1970 from 18.7 to 2.9 for Jews, from 40.1 to 7.2 for Muslims, and from approximately 31 to 4 for Christian and Druze. Breaking the data down by family status reveals further gaps; Infant mortality among Divorced/widows and single mothers is higher than among married mothers $(6.4 \%, 6.8 \%$ and $4.9 \%$, respectively) ${ }^{7}$

26. Despite the fact that gaps between population groups still exist, total infant mortality in Israel (3.9) is low in comparison to other welfare states (Canada, New Zealand and the US, for example), and equal to many others (Austria, France, Germany and Spain, for example) (CBS, 2008a).

27. Finally, in spite of these health improvements, as in other Western countries (World Health Organisation, 2007) obesity is also a growing problem for Israeli children. For example, since 1983 the percentage of 18 year old boys and girls weighing over $81 \mathrm{~kg}$ has doubled. Furthermore, a survey conducted in 2003/4 by the Ministry of Health found that adolescent obesity is more frequent among Arabs than among Jews (The State Comptroller, 2007).

\subsection{Education}

28. The Israeli education system, under the supervision of Ministry of Education, is guided by the Compulsory Education Law and applies to children aged 3-17. ${ }^{8}$ In addition, for children aged 0-3.5, child care arrangements (child care centers and family day care programs) are offered by the Ministry of Industry, Trade and Labor. ${ }^{9}$

29. The Israeli education system (for children aged 3-17) comprised of two main sectors: The state education sector and the ultra-orthodox religious sector. The former, which includes most of the children in that age group, comprises three more sub-sectors: The General sector (mainly seculars Jewish), the religious sector and the Arab sector. Schools and kindergartens in the ultra-orthodox religious sector are privately owned and subsidized by the state but maintain their autonomy with regard to issues of curriculum.

\footnotetext{
${ }^{6}$ According to the World Health Organizaton (2006), in 2004, the European average for males was 69 and for females 77.

${ }^{7}$ Data refers to 2001-2004 averages (CBS, 2008a).

8 Though in regard to the ages of 3-4 and 16-17 the Compulsory Education Law is in the process of implementation and does not cover all localities and children in the country.

9 We deal with the issue of available spots, prices and private arrangements for this age group in the next sections
} 
30. The vast majority of children in Israel between the ages of 3 and 17 spend part of the day in some kind of educational framework. ${ }^{10}$ More specifically, approximately $78 \%$ of the 2453100 children between the ages of 0 and 17 living in Israel are enrolled in the public education system. ${ }^{11}$ Broken down by age group, school enrolment rates for children from ages 5-15 have been above 90\% among all population groups for decades (see table 3.3). Yet many children in other age groups have either not yet entered or dropped out of the educational framework. For example, in the 2007/8 academic year, among students in grades 9 to $11,4.2 \%$ of Jews and $8.0 \%$ of Arabs dropped out of school. ${ }^{12}$ In these grades the number of Jewish immigrant children who dropped out was twice as high as the number of Jewish native-born dropouts. Nevertheless, since the early 90 s there has been a decline in the percentage of students dropping out of school in the $9^{\text {th }}$ to $11^{\text {th }}$ grades in both the Jewish and the Arab sectors (Tzionit, et al., 2009).

31. In comparison to other OECD countries, the enrolment rate among pre-school children in Israel is quite high: $83.7 \%$, compared to an average of $71.2 \%$ in $2007 .{ }^{13}$ Among children aged 5-14 the Israeli enrolment rate is similar to the OECD average: $96.1 \%$, compared to $98.6 \% .{ }^{14}$ Nevertheless, among children aged 15-19 the Israeli enrolment rate is lower: $64.8 \%$, as opposed to $81.5 \%$ (Tzionit, et al., 2009). ${ }^{15}$

\footnotetext{
${ }^{10}$ Some of the children aged 0-3 are enrolled in the childcare system. We discuss this issue later in the section on work and family reconciliation.

${ }^{11}$ Data refers to 2008/9 academic year.

${ }^{12}$ This is the official count of those who formally dropped out and does not include hidden dropouts.

${ }^{13}$ Among children aged 4 and under as a percentage of the population aged 3-4.

${ }^{14}$ Among children aged 5-14 as a percentage of this population.

${ }^{15}$ Among children aged 15-19 as a percentage of this population.
} 
Table 3.3. Rate of Enrollment in the Education system (percentages), by age and sectors, $2007 / 8$ academic year

\begin{tabular}{|c|c|c|}
\hline Age & Arab sector & Jewish and other sectors \\
\hline 3 & 74.9 & 86.1 \\
\hline 4 & 82.8 & 92.8 \\
\hline 5 & 94.5 & 97.1 \\
\hline 6 & 90.5 & $77.6^{*}$ \\
\hline 7 & 97.3 & 96 \\
\hline 8 & 97 & 96.8 \\
\hline 10 & 97.4 & 96.9 \\
\hline 11 & 97.5 & 96.3 \\
\hline 12 & 97.3 & 94.4 \\
\hline 13 & 87.4 & $77.6^{* *}$ \\
\hline 14 & 97.5 & 96.8 \\
\hline 15 & 96.4 & 97.3 \\
\hline 16 & 90.5 & 96.5 \\
\hline 17 & 88.1 & 96.4 \\
\hline
\end{tabular}

* The low rate is due to large share of Jewish children aged 6 attending kindergartens

**The low rate is due to large share of Jewish children aged 12 attending elementary schools

Note: Arab residents of Jerusalem are not included in the student rate due to lack of data regarding many education institutions in the Eastern part of the city.

Source: Tzionit, et al., 2009

32. The Israeli education system includes also an Arab sector in which Arab-speaking Muslim, Christian and Druze students are enrolled. Studies are conducted in Arabic in schools in these population groups. This system includes kindergartens, preschools, elementary and high schools which are official (the state sector), unofficial but under the supervision of the Ministry of Education (the independence sector), government schools, and schools operated by the Welfare and Employment Agency in East Jerusalem. As table 3 indicates, there is a gap in the rate of students enrolled in education institutions between Jewish and Arab sectors. This gap is very prominent under the age of 4, declines at age 5, but increases again at age 15. Furthermore, government spending per child is much lower in the Arab sector than in the Jewish sector. This financial gap is reflected in different ways: First and most directly, average spending per child in the Arab localities is estimated to be $36.8 \%$ lower than in Jewish localities. ${ }^{16}$ Second, and indirectly, the average number of pupils per classroom in Arab schools is higher (for example, in 2007 the average number in the Arab elementary schools was 29, compared to 24.4 in the Jewish schools) (Sikkuy, 2007). Finally, this spending gap is also reflected in the allocated teaching hours. For example, a pupil in the Jewish elementary school system receives 1.88 teaching hours per week on average compared to only 1.45 hours in the Arab system.

\footnotetext{
${ }^{16}$ This estimation is based on comparison between Jewish and Arab localities data (mixed localities were excluded). Data refers to years 2004-2006 (average). Data source: Personal communication with the Union of Local Authorities in Israel
} 
33. One outcome indicator that sheds light on the learning achievements and gaps between the different population groups in Israel is the percentage of those eligible for matriculation diplomas. In the $2005 / 6$ school year, only $45.9 \%$ of all 17 -year-olds - including the residents of East Jerusalem and ultraorthodox Jews - were eligible for a diploma upon matriculation. The percentage of those eligible for matriculation diplomas in the Jewish sector, excluding the ultra-orthodox subgroup, was $58.7 \%$; in the Druze sector it was 44.4\%; in the Arab sector (outside East Jerusalem) it was 35.7\%; and in the Negev Bedouin sector it was $27.9 \%{ }^{17}$

34. Comparing this data to the 1999/2000 academic year, the share of those eligible for matriculation diplomas has risen from $42 \%$ to $45.9 \%$. Nevertheless, this growth masks two major developments and trends: First, the trend has begun to decline since 2003/4, when the share stood at its peak of $49.2 \%$. Second, the reversal of the trend is due mainly to a decreasing share among Arabs - from $42.2 \%$ in $2003 / 4$ to $35.7 \%$ in $2005 / 6$.

35. Another achievement indicator is the share of children whose eligibility for matriculation diplomas meets university entry level requirements. In $2005 / 6,45.7 \%$ of the $12^{\text {th }}$ graders met these entry level requirements, compared to $39.9 \%$ in the 1995/6 academic year. Nevertheless, as in the previous indicator, major gaps exist between the Jews and the Arabs; in 2005/6 the share in the Jewish education system was $47.8 \%$, whereas the share in the Arab system (Muslims, Christians and Druze) was only $35 \%$.

36. Most of the official outcome indicators refer only to learning achievements. Thus, alternative outcome indicators, such as school climate, are not taken into real consideration in the policy decision process. According to a study conducted in 71 primary schools, almost a third of the students reported being emotionally maltreated by a staff member, and more than a fifth reported being a victim of at least one type of physical maltreatment. ${ }^{18}$ The most vulnerable groups for maltreatment were males, students in Arab schools, and students in schools with a high percentage of students from low-income and loweducation families (Benbenishty, Zeira, Astor, Khoury-Kassabri, 2002). Moreover, other studies indicate that school peer violence constitutes a major problem both in absolute and relative terms (see Soen, 2002). For example, a survey conducted by RAMA shows that on average, $13 \%$ of students in grades 5 to 9 reported involvement in direct or indirect violence. ${ }^{19}$ Both elementary school students and Arab students reported involvement in violent events more frequently than middle-school students and Jewish students.

\subsection{Children with Limited Access to Rights}

37. Children living in unrecognised Bedouin localities in the Negev region especially lack adequate access to education, health and other services. Nearly 54,000 children reside in these localities, two-thirds of whom are aged 0-9.Another group of children living in Israel without full rights is children who lack Israeli citizenship. It is difficult to estimate the exact size of this group as it includes, among others, children of undocumented foreign workers who do not register with the Ministry of Interior. Yet among the legally registered children, nearly $6.8 \%$ do not have full Israeli citizenship. More than two-thirds of them are Arab residents of East Jerusalem, while the rest include children of legal foreign workers, immigrant children whose status has not been resolved, and children of mixed marriages between a citizen and a non-

\footnotetext{
${ }^{17}$ Traditionally semi-nomadic Arab tribes indigenous to the southern Negev region in Israel.

${ }^{18}$ Emotionally maltreated was defined as being humiliated or cursed by staff member. Physical maltreatment was defined as being grabbed, shoved, pinched, slapped, kicked or punched by staff member.

${ }^{19}$ The violence measurement included a varied range of violence activities, both direct (being punched, blackmailed, etc.) and indirect ("other student tried to convince other students not to speak with you or not to be your friend", etc.). All students were asked to report about their involment in the last month before the surevey. From: The National Authority for Educational Measurement and Evaluation.

Retrieved August, 2009 from: http://cms.education.gov.il/educationcms/units/rama/odotrama/odot.htm
} 
citizen, especially between an Arab-Israeli and a Palestinian resident of the Palestinian Authority. These children without Israeli citizenship are considered to be at high risk due to their limited rights, including in areas other than education, such as health care. In 2001, a new arrangement of voluntary health care insurance for children of labour migrants was introduced by the Ministry of Health and activated by way of one of the "Sick Funds" operating in Israel. The new arrangement permits labour migrants to pay a fixed monthly fee to purchase health care insurance that is equivalent in content to that provided under the National Health Insurance Law. ${ }^{20}$ Although this agreement is an improvement on the previous situation, the fact that the insurance is voluntary and dependent on the will of the parents (who sometimes lack knowledge of it or the financial resources needed to finance it) leads to very low take-up rates (Asiskovitch \& Shooshy, 2006). ${ }^{21}$

38. As noted earlier, the majority of the children lacking full citizenship are Arab children living in East-Jerusalem. In contrast to other non-citizens (e.g. labour immigrants), these children are entitled to social and health services and covered by the National Health Insurance system. Nevertheless, in contrast to all other Israeli children, in order to utilise their rights East Jerusalem parents need to prove their children's legal status as permanent residents. Because of this prolonged process, many of these children are not effectively covered by National Health Insurance system.

\subsection{Children with Special Needs}

39. Approximately $13 \%$ of children in Israel (roughly 300000 ) have special needs. Two-thirds of them, approximately 180000 or $7.7 \%$ of Israeli children, have a chronic disease or disability that affects their daily functioning, while the others have a chronic disease or deficiency that does not affect their daily functioning. ${ }^{22}$ The Special Education Law (1988) regularizes the rights of special needs children in the education system. It determines the procedures for placement of a child in special education, including appointing Placement Committees, their panel and authorities. In addition, the law determines the length of the school day and school year, the necessary qualifications of teachers and therapists, and rules regarding the dates of presenting an individual learning program for every child. Following the Special Education Law, there are three kinds of special education services: 1) Special classes for children with special needs that operate in schools of general education 2) Special education schools and kindergartens 3) The 'basket' of integration services (the entire array of services provided for special needs children by power of the law, while they are integrated within the general education system).

40. In 2005/6, nearly 46000 children with special needs studied in classes, kindergartens or schools belonging to the special education system. A major proportion of these $(45 \%)$ were in special classes in regular schools, and the rest in special schools $(40 \%)$ or kindergartens $(15 \%)$. As for students with special needs in regular education (entitled to the 'basket' of integration services), between the years 2003/4 and $2004 / 5$ the percentage of integrated students decreased from $7.9 \%$ to $6.5 \%$. Broken down by population group, the percentage of non-Jews with special needs integrated in regular education was lower than that of Jewish students. Broken down by disability type, in 2004/5 over half of the students eligible for integration in regular education had learning disabilities, and approximately $10 \%$ had behavioural problems.

20 This law provides for mandatory health insurance for permanent Israeli residents.

21 According to some estimates, about half of the labour migrants' children living in Tel-Aviv are not insured.

22 This is based on research undertaken between 1995-1997 by the National Insurance Institute and the Myers-JDCBrookdale Institute (2000). Further research that could shed light on the scope and wellbeing of this population group has yet to be undertaken. 


\subsection{Delinquent Youth}

41. Recent years have witnessed a rise in the number of cases of minors suspected of (though not always charged with) committing criminal offences. In 2006, the rate of suspected minor delinquents stood at $2.1 \%$, or less than 15000 . Broken down by population group, the rate for Jews was $1.5 \%$ (3.2\% for Jewish immigrants) and for non-Jews 3.5\%. Most offences were crimes of violence $(50 \%)$ or property crimes $(29 \%)$. In 2007, 85 minors were incarcerated; all others were either punished differently or acquitted of the suspected crime.

42. Breaking down the data by population group, $46 \%$ of all criminal files of minors involved nonJews and $20 \%$ Jewish immigrants. Juvenile delinquency, like adult delinquency, is heavily gendered: almost $92 \%$ of offenders were boys.

\subsection{Children in Distress}

43. More often than being perpetrators of violence, minors are exposed to or are victims of crimes. For this and other reasons, a significant number of children are defined as "children in distress." Distress is defined here as children at risk due to factors that endanger "the child's development or proper living which require assistance, not necessarily removing the children from their home" (Tzionit et al., 2008, p. 502).

44. It is clearly difficult to estimate the scope of this phenomenon, not only because it is underreported but also due to the vagueness of what constitutes a child in distress. This involves more than just the formal definition and identification, as the various authorities dealing with these children employ diverse criteria and have different conceptions of what a "child in distress" means.

45. Israeli law requires every citizen with a reasonable suspicion that a minor is suffering from abuse to report this to the police or to child protection officers, in practice, mostly the latter. In January 2007, nearly 390000 children were known to local social service departments, comprising $16.6 \%$ of all the children in Israel. Since 2001 the number of children known to the local social service departments has increased by nearly $36 \%$, but this increase in needs was not accompanied by a respective allocation of resources.

46. Breaking down the data by risk factors shows that in 2007, of the children who were at direct family risk and who were known to the social service departments, about $46 \%$ suffered from economic difficulties, $46 \%$ had educational and behavioural problems, and $42 \%$ had an emotional or physical disability (or had elderly parents).

47. Children and adolescents may also be at risk due to their own dangerous behavioural patterns, such as alcohol abuse. A comparison between data from an Israeli large scale survey and a similar European study (ESPAD) indicates that the Israeli adolescents (grade 10 and 12) drink alcohol less frequency their European counterparts. In 2007, approximately $60 \%$ of Israeli adolescents had drunk alcohol at least once during the last 12 months, comparing to an average of $82 \%$ in the European countries. As for intoxication experience, the Israeli adolescents are much more similar to the European counterparts. In $2007,33 \%$ of Israeli adolescents reported that they had been intoxicated during the last 12 months, comparing to an average of $39 \%$ in the European countries. Moreover, breaking the Israeli data down to population groups reveals major gaps; In general, Jewish, Jewish immigrants ${ }^{23}$, boys and seculars

\footnotetext{
${ }^{23}$ From the Former Soviet Union.
} 
adolescents drink and intoxicate more often than Arabs, Jewish native-born, girls and religious adolescents, respectively. ${ }^{24}$

48. The use of drugs or any other psychoactive substances also puts children and adolescents at risk. Although, the share of the Israeli adolescents reporting using cannabis at least once for the last 12 months is lower than among their European counterparts (14\%), the share of ecstasy use is much higher $(4.4 \%$ and $2 \%$, respectively). The latter can be largely explained by the use of ecstasy among the Arab adolescents ( $6 \%$ comparing to $2.4 \%$ among Jewish adolescents). ${ }^{25}$

\section{Child Poverty in Israel}

49. Data on poverty levels is published biannually by the National Insurance Institute, the country's social security agency. The poverty line employed by the agency is a relative one and is based on data provided by the Central Bureau of Statistics as compiled in its annual income surveys. It is calculated as $50 \%$ of the median disposable income per standard person of the entire population. An equivalence scale is employed in the scale whereby the number of standard persons in each poor family is equivalent to the square root of the number of persons in the family.

50. Based on this standard, in 2007 there were 412900 poor families in Israel, encompassing 1630400 persons, of whom 773900 were children. $19.9 \%$ of families were classified as poor, $23.8 \%$ of individuals and $34.2 \%$ of children (NII, 2008b).

51. While the official Israeli poverty measurement is similar to that employed by the Luxembourg Income Study (LIS), and the data upon which the calculations are based is comparable, there are differences in the equivalence scales employed. According to the LIS definition, the relative poverty rate in Israel in 2001 was $7.5 \%$ at the $40 \%$ line ( $40 \%$ of median income), $15.6 \%$ at the $50 \%$ mark, and $23.5 \%$ at the $60 \%$ mark. Using a standard capita equivalisation method, the relative poverty rate for children was $7.3 \%$ at the $40 \%$ mark, $18 \%$ at the $50 \%$ mark and $28.5 \%$ at the $60 \%$ mark. At the $50 \%$ benchmark the proportion of poor children in two-parent families was $17 \%$ and among single-parent families $33 \%$ (Luxembourg Income Study, 2009). The table below presents child poverty levels in a cross-national comparative perspective. As can be seen in the table, child poverty levels in Israel are higher than in all other welfare states except the United States.

\footnotetext{
${ }^{24}$ The Israeli data: Schiff \& Benbenishty, 2008. The European data: Hibell, Guttormsson, Ahlströhm, Balakireva, Bjarnason, Kokkevi \& Kraus, 2009.

${ }^{25}$ The Israeli data: Schiff \& Benbenishty, 2008. The European data: Hibell, et al., 2009.
} 
DELSA/ELSA/WD/SEM(2010)4

Table 4.1 Relative Poverty Rates (50\%) among Children in Various Welfare States (percentages)

\begin{tabular}{|l|c|}
\hline State & Relative Poverty Rate \\
\hline Australia 2003 & 13.9 \\
\hline Canada 2004 & 16.8 \\
\hline Denmark 2004 & 3.8 \\
\hline France 2000 & 7.9 \\
\hline Germany 2000 & 8.9 \\
\hline Ireland 2000 & 14.6 \\
\hline Israel 2001 & $\mathbf{1 8}$ \\
\hline Italy 2000 & 16.5 \\
\hline Spain 2000 & 16 \\
\hline Sweden 2005 & 4.6 \\
\hline UK 2004 & 13.9 \\
\hline USA 2004 & 21.2 \\
\hline
\end{tabular}

Source: LIS Key Figures, http://www.lisproject.org 01/04/2009.

52. Most of the components of the poverty measurement approach adopted by the OECD are similar to those in the approach used in Israel, and thus the findings are generally similar. According to the OECD, the incidence of poverty among families, which was $19 \%$ in 2006 , decreased in 2007 to $18.4 \%$, which is not far from the level measured using the Israeli equivalence scale. Additionally, the trends between the two years (and over the course of time) are similar, and the general trends in the analysis by population groups remain unchanged: the poorest population groups are Arabs (43.4\%), large families, families in which the head of the household has a particularly low level of education ${ }^{26}(43.2 \%)$, and families in which the head of the household is of working age, but not employed (68.9\%). The incidence of poverty among immigrants $(19.3 \%)$ is similar to the incidence of general poverty; the incidence of poverty among working families $(9.5 \%)$ is about half the rate of poverty in the general population; and the lowest incidence of poverty was recorded among families with two breadwinners - in 2007 , less than $2 \%$ of these families were poor (NII, 2008b).

53. However, despite the overall similarities in the NII and OECD poverty measurements, there are also some differences, due to the use of a different equivalence scale. Consequently, in the OECD's measurement large families (and as a result, children in general) are perceived as less poor than in the Israeli measurement, whereas small families (e.g., elderly families) are perceived as poorer (NII, 2008b).

54. According to the official Israeli measurement, the incidence of poor families remained stable in 2007: the rate of families whose net income fell below the poverty line was $19.9 \%$ in 2007 compared with $20.0 \%$ in 2006 . The rate of persons living in poor families decreased slightly from $24.5 \%$ to $23.8 \%$. The

\footnotetext{
${ }^{26} 8$ years or less of schooling.
} 
incidence of poor children, which rose over the past decade, from $21.8 \%$ in 1998, showed a decrease for the first time. As can be seen in the table, $34.2 \%$ of children lived in poor families in 2007, compared with $35.8 \%$ in 2006 (NII, 2008b).

Table 4.2 Poverty Incidence (percentages and absolute numbers), 2007

\begin{tabular}{|l|c|c|c|}
\hline & $\begin{array}{c}\text { Before transfer } \\
\text { payments and } \\
\text { taxes }\end{array}$ & $\begin{array}{c}\text { After transfer } \\
\text { payments and } \\
\text { taxes }\end{array}$ & $\begin{array}{c}\text { Rate of decrease in } \\
\text { poverty incidence after } \\
\text { transfer payments and } \\
\text { taxes (\%) }\end{array}$ \\
\cline { 2 - 4 } Families \% & 32.3 & 19.9 & 38.4 \\
\hline $\begin{array}{l}\text { Families in } \\
\text { numbers } \\
\text { Individuals \% }\end{array}$ & 668600 & 412900 & 255700 \\
\hline $\begin{array}{l}\text { Persons in } \\
\text { numbers } \\
\text { Children \% }\end{array}$ & 224600 & 1630400 & 26.8 \\
\hline $\begin{array}{l}\text { Children in } \\
\text { numbers }\end{array}$ & 39.9 & 34.2 & 594200 \\
\hline
\end{tabular}

Source: NII, 2008b.

55. Despite the small decrease in the incidence of poverty among children in 2007, more than one in every three children in Israel lives below the poverty line. Transfer payments and taxes have contributed to a decline in the prevalence of poverty among children, and to its relative stability in the last few years (see Figure 4.1). Recently, however, the capacity of these payments to reduce poverty among children has eroded, such that in 2007 only $14.3 \%$ of poor children were extricated from the poverty cycle. This was particularly the case during the first half of the current decade, due to cutbacks in some transfer payments, particularly child benefits.

Figure 4.1 Poverty Prevalence among children (percentages), across years*

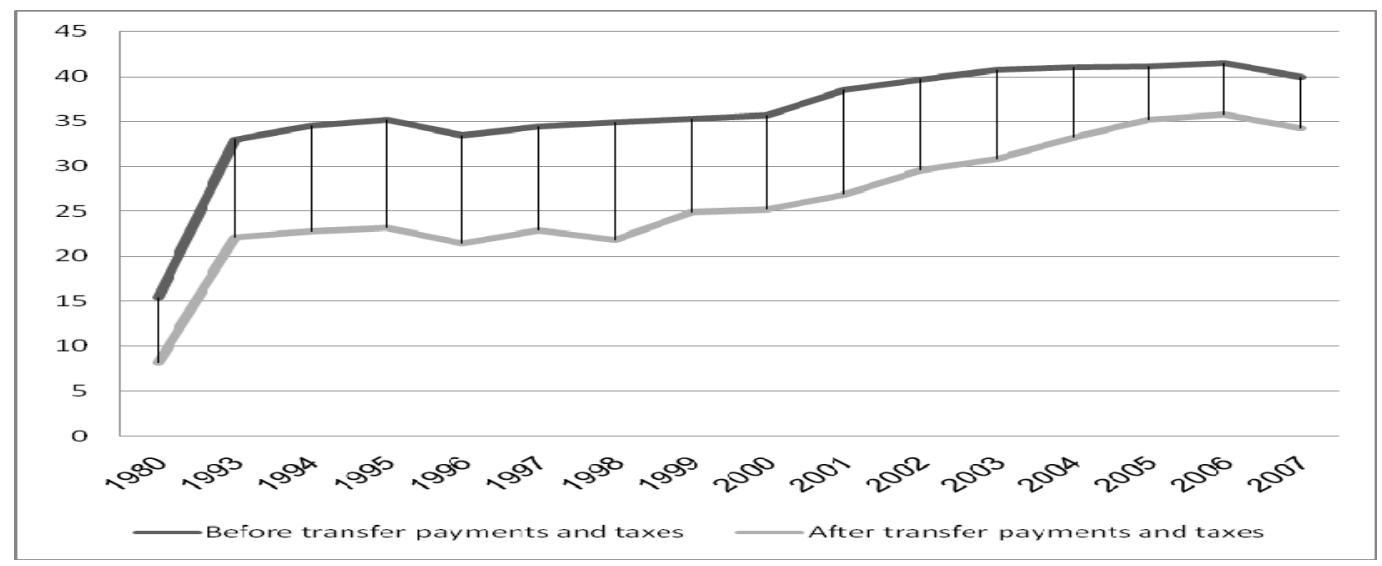

* Until 2001, data did not include children from East Jerusalem. Since 2002, these children were included in the date.

Source: Tzionit et al., 2008. 
56. Child poverty is most prevalent in families with four or more children: approximately $56.5 \%$ of these families had income below the poverty line in 2007 (after transfer payments and taxes). Broken down by population group, the incidence of poverty among Jewish families (15\%) was less than a third of that of Arab families (51.4\%) (NII, 2008b). The incidence of poverty among Arab families, which is very similar to the incidence among large families, decreased from $54 \%$ in 2006 to $51.4 \%$ in 2007 . This may be partially explained by an increase in the economic income of Arab households: the economic income per standard person in the Arab working-age population grew at a rate of about $9 \%$ between the two years. Similar to the Arabs, in 2004, 54.2\% of all ultra-orthodox Jewish families were poor (Gottlieb, 2007). The poverty rates of both groups are consistent with the high proportion of children among their total population.

57. A third population group with greater levels of poverty, besides Arabs and ultra-orthodox Jews, is the single-parent family group. More than $46.9 \%$ of these families live below the poverty line (before transfer payments and taxes). Nevertheless, transfer payments and taxes are most effective in alleviating poverty among single-parent families, reducing poverty by over $36 \%$ in 2006 and leaving approximately $30 \%$ of these families below the poverty line (NII, 2008b).

58. The incidence of poverty among working families remained stable at $12.2 \%$. Poor working families constitute about $46 \%$ of all poor families and about $60 \%$ of all poor families of working age (NII, 2008b).

59. There has also been a dramatic change among children of immigrant families. Initially, the arrival of a large influx of immigrants from the former Soviet Union and Ethiopia at the beginning of the 1990s contributed to a rise in poverty levels. In 1991, the poverty prevalence among immigrant children (before transfer payments and taxes) stood at $74.3 \%$, but this dropped to $44 \%$ in 1995 and normalised slightly above the average poverty rate by 2000 . Benefits for immigrant families helped bring the percentage of immigrant families living below the poverty line down to $43 \%$ in 1991, and the rate stabilised at around $25 \%$ between 1995 and 2006 (27.3\% in 2006).

60. A breakdown by education group of the head of the household shows that the frequency of poverty among those with little education (up to 8 years of schooling) was 3 times higher than the poverty rate among those with higher education (13 or more years of schooling). The severity of the former's poverty, which increased significantly between 2006 and 2007, was 5 times greater (NII, 2008b). ${ }^{27}$

61. The geographical distribution of the poverty findings shows that the scope of poverty among families in the Haifa and central areas decreased between 2006 and 2007, but increased in regions already characterised by relatively high poverty rates, in particular Jerusalem and the periphery (NII, 2008b).

\section{Parental Employment in Israel}

62. In 2008, $63.8 \%$ of the working-age population (15-64) participated in the labour market. Among men, the labour market participation rate was $68.1 \%$, and among women $59.5 \%$ (OECD, 2010). The participation rate of mothers was significantly higher than for women without children $(67.3 \%$ versus $44 \%){ }^{28}$ Nevertheless, this gap is mainly due to age differences. Thus, when comparing these two groups among different age clusters, mothers' participation rate is almost always lower (except among women

\footnotetext{
${ }^{27}$ As measured by the FGT index.

${ }^{28}$ Data refers to total population (age 15 and over).
} 
aged 55+). Moreover, as the number of children increased, and as the age of the youngest child decreased, the participation rate of mothers fell (CBS, 2009b). ${ }^{29}$

63. In comparison to OECD countries, Israel's male workforce participation rate is low: in 2008, the participation rate among Israeli men at working-age (15-64) was $68.1 \%$, as compared to the OECD average of $80.5 \%$. In contrast, among women the participation rate was only 2 points lower than the OECD average: $59.5 \%$ as compared to $61.3 \%(\mathrm{OECD}, 2010)$.

64. Broken down by population group, the participation rate of working-aged Arabs (44.1\%) in 2007 was much lower than the rate among Jews (69.5\%). However, it is worth mentioning that the disparity between these groups stems mainly from the women: whereas the participation rate among Jewish women was $68.3 \%$, the rate among Arab women was only $22 \%$. In contrast, the participation rate among Arab men (65.6\%) was only slightly lower than among Jewish men (70.8\%) (OECD, 2010).

65. Another population group with an extremely low labour force participation rate is the Jewish ultra-orthodox group, particularly men. In 2004, the participation rate of the latter was $36.9 \%$, compared to $67.7 \%$ among the remainder of the male Jewish population. As for women, the participation rate of the ultra-orthodox was $48.4 \%$, compared to $57.5 \%$ among other Jewish females (Gottlieb, 2007). ${ }^{30}$

66. In terms of employment rates, Israel was ranked below the OECD average in 2008. The employment rate among the working-age population (15-64) was 59.8\%, compared to an OECD average of $66.5 \%$. This gap is especially noticeable among men: the employment rate among Israeli men was $64.1 \%$, compared to an average of $75.7 \%$ in the OECD countries. Among women the gap is smaller: $55.6 \%$ for Israeli women and an average of $57.5 \%$ for OECD countries (OECD, 2010).

67. In 2007, $13.2 \%$ of children in Israel lived in households without any employed persons. Breaking the data down by population group, $11 \%$ of Jewish children and $19 \%$ of Arab children lived in this type of household. Moreover, $66 \%$ of Jewish children, compared to $31 \%$ of Arab children, lived in households with two or more employed persons (CBS, 2009b).

68. The average monthly wage in the Israeli workforce in 2008 was 8060 (NIS). Nevertheless, data indicates that over $60 \%$ of the workforce earns less than the average wage, with many earning close to the minimum wage of 3850 NIS.

69. As suggested in section 4, a two-parent family with four children with both parents earning the minimum wage is likely to earn an income that places it above the poverty line. By contrast, a singleparent family with two children in which the sole provider is earning the minimum wage will be situated well below the poverty line.

70. Not surprisingly, working families suffer less poverty than non-working families; In 2007, the poverty rate among families with a working head of family was $12.2 \%$, compared to $69.8 \%$ among nonworking families. Moreover, the poverty rate among working families with one wage-earner $(23.5 \%)$ was about eight times higher than families with at least two wage-earners $(2.8 \%)$. Nevertheless, during the last few years there has been a consistent rise in the rate of poverty among working families in general, and among families with a single wage-earner, in particular. Thus, the rate of poverty of families with only one wage-earner rose from $16.4 \%$ in 2002 to $23.5 \%$ in 2007 (NII, 2008b).

\footnotetext{
${ }^{29} \mathrm{We}$ discuss the issue of work and family reconciliation in the section below.

${ }^{30}$ Data refers to total population
} 
71. The unemployment rate among working-age population was $7.4 \%$ in 2007 . The rate among Jews was $6.9 \%$ and among Arabs 11.1\% (OECD, 2010). The rate increased during 2008 and during most of 2009.

72. The number of children living in families in which at least one parent receives unemployment insurance payments has decreased considerably since the year 2000. In 2006, 53,000 received these payments. This significant decrease does not primarily reflect a reduction in the level of unemployment in Israel, but rather is a consequence of changes to the unemployment insurance program, which have curtailed access by introducing more stringent qualifications for receiving unemployment benefits (Gal, 2005). As a result, the data only partially reflects the prevalence of children living in households in which a parent is unemployed.

73. Notably, during the last decade there has been a more marked effort by the state to increase labour market participation rates and to move individuals from welfare to work, including through the "welfare to work" program (Orot Letaasuka or, formerly - Mehalev) which is currently in its fourth year of a trial in four different localities. Recipients of social assistance benefits (income support) who are under the age of 45 and reside in these localities are required to participate. In addition, a number of programs have been introduced on a voluntary basis by non-state or quasi-state organisations (TEVET, for example).

\section{Support for Families and Children in the Benefit and Tax Systems}

74. Families with children are one of the main recipient groups of the benefit and tax systems. To a large degree this is a consequence of the large proportion of children in the Israeli population, but it also reflects a traditional formal commitment to the welfare of children, a recognition that poverty is particularly prevalent in families with a large number of children, and pressures from the political system, primarily from the political representatives of the ultra-orthodox community.

75. There are a number of systems within the Israeli welfare state intended for children and/or families with children. These include:

1. Direct payments through the social security system: In 2008, expenditure devoted specifically to families with children comprised over $11 \%$ of total social security spending, 5109 million NIS. An additional 2392 million NIS (4.9\% of total spending) was devoted to providing families with a safety net. In addition to benefits directed to children are transfer payments that enable parents to reconcile work and family. These include Maternity Benefits, Paid Maternity Leave and other kinds of benefits directed at parenthood. In $2008,9 \%$ of all social security spending went to these programs (NII, 2008c).

2. In addition to transfer payments, the state offers a number of tax advantages to families with children and has recently introduced a limited negative income tax program, which provides additional incomes to low-income working families with children in some parts of the country (Ministry of Finance, State Revenues Administration, 2008).

3. Early childhood education: In order to reconcile work and family responsibilities, the state offers some families, depending on their level of income and other criteria, financial assistance in the form of subsidies for early childhood education and care. The state also regulates at least part of early childhood education in the country (for more information see the next section).

76. Nevertheless, the actual tax and benefit package for families with children in Israel is not particularly generous, nor is it diversified. Moreover, in recent years the generosity and accessibility of social security benefits for families and children have been undermined, though this has not generally been the case for the other two major groups of benefit recipients - the elderly and people with disabilities. 
Indeed, to a certain degree, the benefits for members of these groups have become more generous and accessible (though they often remain low in actual terms). A breakdown of National Insurance Institute (NII) expenditure on benefits is indicative of this trend. As can be seen in the figure below, the proportion of the NII expenditure on benefits for families with children (child benefits) dropped from $17 \%$ in 2001 to just below $11 \%$ in 2007 , while expenditure on the elderly grew from $34 \%$ to $37 \%$ during this period, and that for the disabled grew from $13 \%$ to over $19 \%$.

Figure 6.1 Proportion of National Insurance Institute Expenditure on Benefits

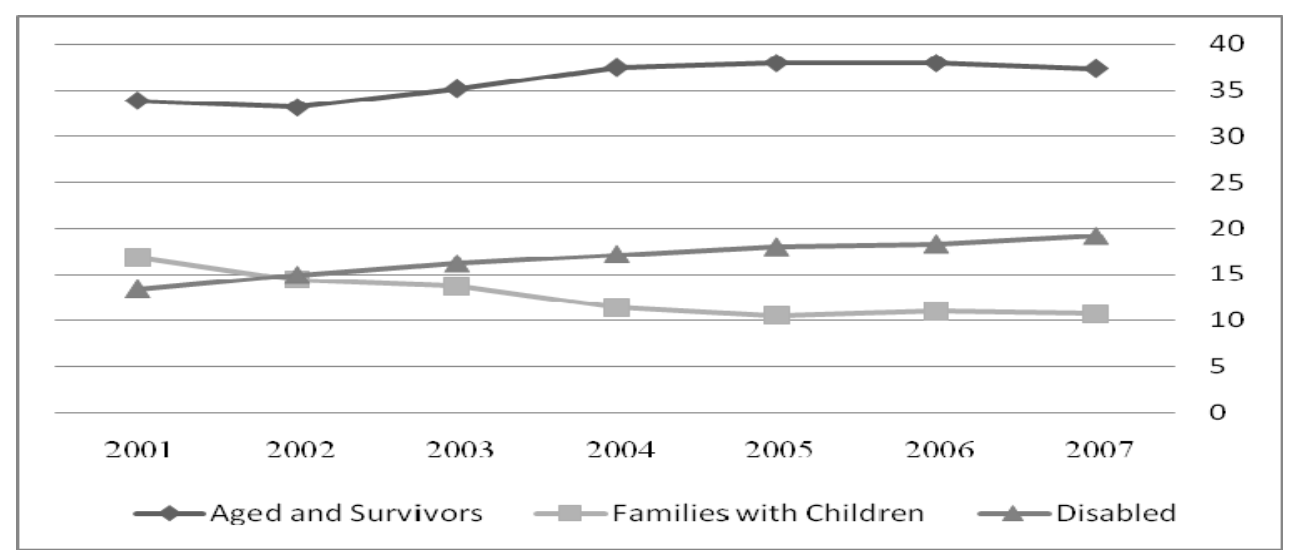

Source: NII, 2008a.

77. Recent political developments have influenced this trend to some degree. The coalition agreements of the current government have led to an increase in accessibility to unemployment insurance benefits and in the generosity of child benefits. Both of these should raise the volume of benefits for families with children and lead to greater expenditure on social security benefits for families with children.

78. From an historical perspective, the social security system for families with children was effectively consolidated from the mid-1970s onwards. The introduction of a series of measures - in particular unemployment insurance and universal child benefits during the 1970s, and then income support and benefits for disabled children in the following decade, followed by benefits targeted at single-parent families in the early 1990s - created a relatively comprehensive system of social security benefits for families with children.

79. These developments, together with the influx of immigrant families and the economic difficulties during that decade, led to growth in social security spending on families with children during the 1990s and a marked increase in the number of recipients of benefits among families with children. This was particularly the case for safety net benefits such as income support and supplements for single-parent families. These trends were reversed from 2002 onwards. Income supplements, child benefits and other benefits were cut and the conditions for eligibility made more stringent.

\subsection{Cash Transfers}

80. Support for families with children through cash transfers, in the form of allowances and benefits administered by the NII, or in some cases by government agencies, takes different forms. Some benefits are universal and reach all families with children, while others are means-tested and are targeted to specific populations. Universal benefits intended for all families with young children include: 
81. "Child Benefits" are paid by the NII to every citizen who is a guardian of at least one child under the age of 18, regardless of income. Since 1996 the benefits have been universal and equally paid to the entire population. ${ }^{31}$ Until May 2003, the amount of benefits given to a family depended on the number of children; Families with three children or more received higher benefits. In May 2003, the benefits were cut dramatically, and it was decided that all families would receive the same amount for every additional child born after that date, without taking into consideration the total number of children in a given family. In 2008, the benefit level for each child born after June 2003 stood at 159 NIS. In that year, 994753 families received this benefit (NII, 2008c). In mid-2009, additional changes were introduced into the Child Benefit structure. As a result, the $3^{\text {rd }}$ and $4^{\text {th }}$ children in a family will gain 60 NIS and 153 NIS per month (respectively) in addition to the basic amount.

82. "Maternity Benefit" is paid to all mothers who give birth in a hospital, or to mothers who had hospital admission just after birth, with benefits increasing for multiple births. The expressed goal of this benefit is to help families with the initial expenses associated with having a child. In 2008, 93630 mothers received this benefit (NII, 2008c).

83. "Paid Maternity/Paternity Leave" is paid to all working mothers. It is intended to compensate the mother for the loss of salary or income during the period in which she does not work due to pregnancy and giving birth. Since 2008, paid maternity leave has been calculated as $100 \%$ of the mother's average income from the three months prior to birth and is paid for 14 weeks. The law was amended in 1998 to enable the father to take paid leave instead of the mother, but only after the mother has taken paid leave for at least the first six weeks after giving birth.

84. "Paid Adoption Leave"- Parents adopting a child under the age of ten are also entitled to paid adoption leave with regulations similar to those of paid maternity leave.

85. "Allotment for Newborns whose Mother Died" - If the mother dies during childbirth or within one year of birth, a special payment will be paid to the newborn, on the condition that the mother was entitled to a maternity grant and/or childbirth benefit and/or maternity benefit.

86. "Benefits for Children Orphaned due to Domestic Violence" - The National Insurance Institute pays benefits to children who have been orphaned due to domestic violence. By 2006, 152 children had received benefits due to the death of a parent from violence inflicted by the spouse.

87. "Benefits for Children of Parents Killed in the Israel Defence Forces" - A child benefit is paid by the Ministry of Defence to children orphaned due to their parents' death while participating in military activities.

88. “Benefits for Child Victims of Terrorist Attacks" - This benefit is paid by the NII to children who have been orphaned or disabled by terrorist attacks.

89. There are various benefits for orphan children: A "Maintenance Benefit for Orphans" is paid to a child who dedicates most of his/her time to high-school studies or to vocational training. "A Bar/Bat Mitzvah Grant" is paid to a boy-orphan who reaches the age of 13 and a girl-orphan who reaches the age of 12. "Survivor Benefits" are paid to the widow or widower and/or orphan (child under the age of 22 if

\footnotetext{
${ }^{31}$ Between 1970 and 1996, a supplementary child benefit was paid to families with three or more children in which at least one family member had participated in military service. Immigrants and ultra- orthodox families were also eligible. As a result, large Arab families were the only group excluded from access to this benefit. For a discussion of this benefit, see Rosenhek, 1999.
} 
he or she serves in the army) of a deceased Israeli resident who was insured for Old-Age and Survivor's Insurance for the period required by law and who paid the insurance payment as required by law.

90. "Disabled Child Benefits" is a benefit paid to families of disabled children. Benefit recipients must be 91 days to 18 years old. Families with two or more disabled children are entitled to a pension at an increased rate for each child. In 2008, the monthly benefit paid to a family with a disabled child was 1945 NIS, with 25555 recipients that year (NII, 2008c).

91. Benefits that are not universal but that are paid according to individual circumstances are listed below:

92. "Maintenance" (Alimony) - The Maintenance Law is designed to assist women and children who have a court judgment for maintenance payments but are not receiving those payments from the person obligated to pay (the spouse). In these cases, the NII provides them with a monthly payment and collects the amount from the debtor. The amount paid to a woman by the NII is the amount determined by the court or the maximum amount of the benefit, whichever is lower. In any case, the right to maintenance payments from the NII is contingent upon an income test. Recipients of this benefit are not eligible for the social assistance benefit (Income Support). During the years 2002-2006 period, there was a decrease in the number of recipients, due in part to more stringent legal stipulations for receiving this payment. In 2008, 20783 recipients received this payment (NII, 2008c).

93. "Income Supplement Benefits" are partial benefits paid to a person whose income from work or from another source is lower than the minimum income required for subsistence. "Income Support Benefits" are full benefits paid to a person who is not capable of earning income from work. Both income supplement and income support benefit applicants must meet three basic conditions of entitlement: First, continuity of residency requires a resident of Israel to be in Israel for at least 24 consecutive months and to be at least 20 years of age. Second, means tests determine whether the income of a single person or a couple does not exceed a certain amount, which is determined by age, family status and the number of children in the family. Third, there is an employment test that determines: 1) whether a person is unemployed and registered with the employment service from which he or she is requesting work under the rules determined by the employment service; 2) whether a person is participating in vocational training and; 3) whether a person is working for a low salary, or is a participant in the Israeli welfare to work program (where relevant). The monthly benefit for a family of four (two adults and two children), which is completely dependent on the benefit as a source of income, is currently 2574 NIS. A single-parent family with two children receives 2996 NIS per month. In 2007, 120220 recipients received Income Support/Supplemental Benefits. Among them, 17331 were single parents who had one child and 15028 who had two or more children. In addition, 4340 couples with one child and 21457 couples with two or more children received the benefit during the same year (NII, 2008c).

94. The rate of receipt of income support benefits for veteran Israeli couples with children is $21.5 \%$, while only $5.4 \%$ of immigrant couples with children receive this benefit. Among veteran single-parents, $28.8 \%$ receive income support benefits, while $38.5 \%$ of immigrant single-parents receive these benefits.

95. A parallel income support system is administered by the Ministry of Education for ultra-orthodox full-time adult Yeshiva students. As these students are unable to undergo a work test (as they study fulltime) and thus cannot apply for Income Support, they are eligible for social assistance that is conditional on an income test and on their being the parent of at least three children. This program currently provides monthly benefits to 10851 Yeshiva students at a cost of 110 million NIS per year. 
96. In 2007, the NII paid out benefits amounting to 46 billion NIS, or $7 \%$ of GDP. As can be seen in the table below, $11 \%$ were devoted to child benefits, $8 \%$ to maternity benefits and $5 \%$ or less to unemployment insurance and to income support benefits.

Table 6.1 National Insurance Institute Benefit Payments, 2008 (\% of all payments)

\begin{tabular}{|l|c|}
\hline \multicolumn{1}{|c|}{$\begin{array}{c}\text { Type of Benefit } \\
\text { Payment }\end{array}$} & $\begin{array}{c}\text { Share of all Benefits } \\
\text { Payments }\end{array}$ \\
\hline Old-Age and Survivors & 38 \\
\hline General Disability & 19 \\
\hline Children & 11 \\
\hline Maternity & 8 \\
\hline Work Injury & 7 \\
\hline Long-term Care & 7 \\
\hline Income Support & 5 \\
\hline Unemployment & 4 \\
\hline Reserve Duty & 2 \\
\hline
\end{tabular}

Source: National Insurance Institute, 2008c.

97. One key indicator of the effectiveness of transfer payments is their impact on extrication from poverty. In recent years, we have witnessed a gradual decrease in this impact; whereas in $2001,47.4 \%$ of the families were extricated from poverty by transfer payments (and taxes), in 2007, only $38.4 \%$ families were extricated. This growing inability to lift families out of poverty is even more marked for children: $30.1 \%$ of children were extricated from poverty as a result of transfer payments in 2001 , as compared to only $14.3 \%$ in 2007 (NII, 2008b).

\subsection{Tax Expenditures}

98. These also provide an indirect source of support for families with children, in that they provide them with relief from taxation. The tax expenditure system in Israel is relatively large and is projected to equal $5 \%$ of GDP in 2009. A number of specific programs in this system target families with children. Thus, child benefits, maternity benefits and additional benefits targeted at families with children are not taxed. In addition, families in which a family member is a carer for a disabled child are eligible for tax advantages. Single-parent households and working mothers are also eligible for tax advantages. In all, tax advantages targeting families with children were projected to comprise a total of 2110 million NIS, or $5.4 \%$ of all tax expenditures (Ministry of Finance, State Revenues Administration, 2008).

99. Finally, legislation adopted by the Knesset (Israel's parliament) in December of 2007 led to the adoption of an experimental Negative Income Tax scheme in four regions in Israel. The scheme, which began in 2008, offers low-income working families with children the opportunity to receive income of up to 420 NIS per month, depending upon the income level and number of dependent children. The estimated take-up level of this new tax scheme is relatively low, 38.5\% according to Bank of Israel estimates (OECD, 2010). 


\section{Work and Family Reconciliation}

100. Israel lacks a comprehensive, integrative and consistent long-term policy to reconcile work and family responsibilities. Nevertheless, various aspects of the Israeli welfare state, including protective legislation, cash transfers and in-kind services, do contribute to work and family reconciliation. In this context, studies indicate that certain segments of the population, particularly Jewish women and those employed by the state, are better able to reconcile work and family (Okun, Oliver \& Khait-Marelly, 2007). The role of benefits and tax expenditures is clearly crucial, particularly those specifically intended to enable parents (and particularly women) to better balance responsibilities in these two domains. Maternity benefits are a clear example of this type of benefit. The regulated and subsidised early childhood education system also plays a potentially crucial role in the work and family reconciliation process. As we discuss below, 89892 children aged $0-3.5$ were enrolled in that system in $2008 .^{32}$

101. Similarly, a body of protective legislation also contributes to work and family reconciliation. Soon after its establishment, Israel enacted the Employment of Women Law (1954), which sought to better enable women, and especially mothers, to participate in the labour market. Over the years the law was modified and extended, and together with other laws and regulations, it is now considered to be liberal and advanced, protecting women in the labour market (Izraeli, 1992). Clause 6 of the law provides for paid leave during pregnancy, maternity leave for fourteen weeks, and pregnancy-related medical examinations. Clause 7 provides for paid leave for the purpose of fertilisation treatments. The law further prohibits employers from demanding that women work during maternity leave. The law guarantees women paid leave for the purpose of child care and during times of illness among family members. Clause 9a prohibits the dismissal of pregnant women or women undergoing fertilisation treatment who have worked for at least six months with the same employer. An employer who wishes to dismiss a pregnant woman must obtain permission from the Ministry for Industry, Trade and Labour (the ministry responsible for enforcing labour laws). The minister is required to examine the request and grant permission only after being convinced that the request is not related in any way to the pregnancy or to the fertilisation treatments. The law guarantees mothers the same position after returning from leave, and the 1998 amendment prohibits any cutback in a pregnant employee's post as a result of childbirth that would lead to a salary reduction. Section 7 of the law extends the legal defence to women living in shelters for battered women and requires the employer to consider this as paid leave. Mothers are entitled to be absent for up to an hour a day at the employer's expense for breast-feeding. According to Section 7 of the 1963 Dismissal Compensation Act, a mother who resigns within nine months after giving birth in order to care for her child is entitled to compensation.

102. Other laws prohibit gender-based discrimination in the workplace. According to the 1996 Equal Pay law, equal wages must be paid to employees of both sexes for comparable work. The 1988 Equal Employment Opportunities Law prohibits discrimination in the area of personnel recruitment, selection, or promotion on the basis of attributes such as gender, sexual orientation, age, race, religion, and nationality. The 1998 Harassment Prevention Act sets heavy punishments for sexual harassment in the labour market.

103. Nevertheless, despite this impressive body of protective legislation, the level of enforcement of labour laws is often very limited, particularly in the case of excluded social groups, among them Arabs, immigrants and poor mothers. Recent studies indicate that the rights of many women workers in general, and mothers in particular, are abused, and the impact of labour laws on their work conditions is minimal. For example, $53 \%$ of women who returned to their jobs after maternity leave were moved to another job by the employer. Empirical data also points to a steady rise in employers' requests to approve dismissal during

\footnotetext{
${ }^{32}$ Data refers both to Childcare Centers and Family Day Care Programs regulated by the Ministry of Industry, Trade and Labour.
} 
pregnancy. ${ }^{33}$ When dismissed, women can appeal to the justice system, but they hardly ever do. The women in these cases are permitted to present their case to the Ministry during the process and are allowed to be represented by a lawyer. Nevertheless, because most women are unaware of their rights, few of them take advantage of this provision. In addition, those who are aware of these rights are often unable to finance the necessary legal expenses (Ajzenstadt, in press).

104. Apart from cash transfers, tax expenditures and protective legislation, in-kind services that are provided, subsidised or regulated by the state offer paths that further work and family reconciliation. Israel has a relatively sophisticated network of preschool education institutions - governmental (either national or local), non-governmental, and private - that enables parents to reconcile family and work. Preschool education in Israel is divided into two separate systems: early childhood education, which enrols children aged 0 to 3.5, and which is under the supervision of the Ministry of Industry, Trade and Labour; and kindergartens (including day-care nurseries) which enrol children aged 2 to 5 , and which are under the supervision of the Ministry of Education.

105. The origins of the early childhood education system can be found in the pre-state mandatory period during which non-state organisations within the Jewish community, particularly those affiliated with the Labour Movement, established crèches and kindergartens for the children of working mothers. These services were further developed after the establishment of the state by a number of large non-state women's organisations. A major effort to develop this system was undertaken in the early 1970s as part and parcel of state policies intended to increase female labour market participation during a period of full employment. Support for the establishment of daycare centers and subsidies for the children in these centers were integral parts of this policy (Ajzenstadt \& Gal, 2001; Sheffer, 1999).

106. Over the last decade, there appears to have been growing state readiness to support child care services and to encourage the participation of infants in this system, both due to labour market concerns and in response to a growing understanding of the contribution of quality childcare to human capital development. Nevertheless, the regulated early childhood education system in Israel is still relatively expensive for parents, primarily from the middle classes, who either do not receive state subsidies at all or receive low subsidies (see Table 7.1). The parental financial burden is made even more pressing by the geographical distribution of the subsidised services and their often limited density, which creates problems with accessibility, especially for the Arab population (Holler \& Gal, in press). In addition, the regulation of this system is problematic, and consequently provision is not always of good quality (Laor \& Ben-Arieh, in press).

\footnotetext{
${ }^{33}$ In order to convince the Ministery of Industry, Trade, and Labour that the dismissal is not related to pregnancy, employers cite declining need of manpower in the workplace, non-compliance on behalf of the employee with workplace rules, and interpersonal problems.
} 
Table 7.1 Child Care Cost*, after subsidies (percentage of the APW)**

\begin{tabular}{|l|c|}
\hline \multicolumn{1}{|c|}{ Country } & Child Care net cost (\% APW) \\
\hline Australia & 22 \\
\hline Finland & 12 \\
Germany & 11 \\
\hline Is rael & $\mathbf{3 1}$ \\
U.K. & 43 \\
\hline OECD average & 17 \\
\hline
\end{tabular}

\footnotetext{
* The calculations relate to full-time care for two children aged 2 and 3 in a typical childcare center.

** Date refer to two earners with full-time earnings of $100 \%$ of the average production worker's wage (APW).

Source: For Israel data: Holler \& Gal, in press; for other countries, see OECD, 2007.
}

107. Over two-thirds of Israeli children, aged 2-5, attended a public or private preschool education setting in the 2007/8 academic year. This percentage is lower in the Arab sector than in the Jewish sector, especially among 2-year-olds. In both sectors the percentage rises with age. ${ }^{34}$ More specifically, in the Jewish population group, the enrolment rate is $61 \%$ for age 2, $88 \%$ for age 3, $94 \%$ for age 4 and $98 \%$ for age 5. In the Arab population (without East Jerusalem), the gap is particularly acute with regard to children under the age of 2 . Enrolment rates for this age group is merely $14 \%$, though it increases to $75 \%$ for 3 year-olds, $83 \%$ for 4 -year-olds and 95\% for 5-year-olds (CBS, 2009b).

108. The fact that the Ministry of Industry, Trade and Labour, and not the Ministry of Education, is responsible for childcare arrangements for children at ages 0-3.5 is indicative of the fact that the state's aim is primarily to support working mothers and not necessarily to deliver high-quality educational services. While these services are provided by non-governmental and private organisations, the Ministry of Industry, Trade and Labour provides a subsidy for day care (between 5\%-70\%) for working mothers of children aged 3 months to 3 years, according to a sliding scale based mostly on income level. The subsidy is also given to mothers of at-risk children and single mothers. The Ministry of Education together with the local municipalities is responsible for providing educational services to children ages $2-5$, through a number of pre-school and kindergarten frameworks.

109. In 1998, the Knesset approved The Extended School Day Law to making possible for children to study eight hours a day four days a week, and five hours a day on the remaining two days. The period for incorporation of this legislation was slated to be 10 years, but due to repeated postponements it has still not yet fully implemented. However, implementation in the lower socio-economic localities has begun. Those aspects of the law relevant to young children are administered by the Division of Early Childhood Education (Pre-kindergarten) within the Ministry of Education.

110. For slightly older children there are afternoon child care facilities that provide a solution for working parents with after-school supervision of children aged three to eight. These facilities generally include lunch and extra-curriculum activities.

\footnotetext{
${ }^{34}$ The preschool education in Israel is divided into two separate systems: early childhood education and the kindergartens (including day-care nurseries). In the latter, children aged 2 to 5 are enrolled, and it is under the supervision of the Ministry of Education.
} 
111. Child care and educational services that supply educational frameworks at the parents' work place can help whenever the educational system does not provide adequate solutions for late working hours. Given that the vast majority of Israeli workplaces are relatively small and the number of employees limited, few find it worthwhile to maintain educational frameworks for their employee's children. In most cases, employers prefer to offer flexible working hours and vacations to deal with employees' childcare needs. During Israel's summer vacations there are substantially more employers that organise child care activities for employee children. Summer programs are also provided by the Israeli Association of Community Centres, municipalities and other NGOs (Ajzenstadt \& Laor, in press).

112. Working parents have a real need for flexible working hours or part-time work, and the Israeli economy is relatively generous in this regard. Some employers grant their workers special or emergency vacations in order for parents to care for their children if they fall sick or have other urgent problems. Another method to ease the strain on working parents is to provide scholarships and stipends so that they can afford the relatively expensive child care. Information, counselling and support services are additional means to enable parents to combine family and work. Other services such as food vouchers, diapers and rooms for nursing women provide additional help.

\section{Child and Family Services}

113. The public sector and the non-governmental sector provide a wide range of services for parents and children, focusing on their general wellbeing on the one hand and the ability to work on the other.

\subsection{Preschool Education}

114. As noted above, the responsibility for preschool education in Israel is divided between the Ministry of Education and the Ministry of Industry, Trade and Labour. According to official estimates, about 444904 children (79.8\%) aged 2 to 5 were in a preschool education setting during the 2007/8 academic year. Broken down by population groups, major gap between Jewish and Arabs enrolment rates emerge: $84.9 \%$ of the Jewish children compared to only $67.4 \%$ of their Arabs counterparts. This gap is mainly among younger children (among 2 years old children, $61.3 \%$ of the Jewish children compared to $13.7 \%$ among the Arabs) and declines dramatically at age 5 (97.5\% and 94.5\%, respectively) (CBS, 2008a).

115. Due to lack of annual official measurements regarding infants and toddlers arrangements, the available latest estimation is rough and based on date from 2004 survey, According to this estimation, 59,088 children $(23.3 \%)$ aged 0 to 1 were in some kind of early childhood education setting during the $2007 / 8$ academic year. $16.3 \%$ were in recognised and supervised settings while $7 \%$ were in private unrecognised settings. Additional estimation regarding this age group indicate that enrolment rate among the Arab children is very limited and hence not reliable for estimation (Fichtelberg, 2008).

116. Kindergartens (including day-care nurseries) - municipal, public, and private preschool kindergartens (age 5) and nurseries (ages 4 and 3) all operate under the supervision of the Ministry of Education. According to the latest (2004) estimates, 357,282 (87.1\%) children were enrolled in these settings $(344,922$ or $84,1 \%$, in municipal or public settings). Moreover, these numbers reflect a gradual increase in the numbers and share of children enrolled, especially in the Arab sector. For example in 2004, $58 \%$ of Arab 3-year-olds were enrolled, compared to only $21 \%$ in 1998 . Nevertheless, the rate for the Jewish children is still much higher (66.6\% in 2004) (CBS, 2007). In 2008, the overall expenditure on kindergartens was 2,386 million NIS. In per-child terms, in 2007 expenditure was 5484 NIS, an increase of $12 \%$ from 1998 (Horev \& Kop, 2008). 
117. Day Care Centers provide early childhood education for infants aged 0 to 3.5. Currently most of these centers are operated by non-governmental organisations (NGOs) and are under the responsibility of the Ministry of Industry, Trade and Labour, which provides subsidies for working parents, as detailed in the previous chapter. The Ministry estimated that in 2008 there were about 77605 children enrolled in regulated day care centers (Fichtelberg, personal communication, 05/04/2009).

118. Most day care centers are operated by non-governmental organisations, including various women's organisations (such as WIZO, Na'amat and Emuna), the Israel Association of Community Centres (IACC), and other political or religious movements. The latter is most prevalent among the Arab and the ultra-orthodox population.

119. Family Day Care Program "Mishpachton" - this is a program operated by a single caregiver who provides group care and education in her home for up to five children, aged 3 months to 3 years. The caregiver is provided with guidance, training, and supervision either by the local welfare department or by the Israeli Association of Community Centres (IACC). Overall responsibility is in the hands of the Ministry of Industry, Trade and Labour, which estimates that in 2008 there were about 12287 children enrolled in regulated Family Day Care Programs (Fichtelberg, personal communication, 05/04/2009). ${ }^{35}$

120. Afternoon Child Care Facilities operate during the afternoon and often include lunch and enrichment activities.

121. In addition to services provided by governmental and non-governmental organisations, there are also many private unlicensed educational services available. Although Israeli law prohibits private unlincensed day care centers, they are nevertheless very common. These centers are not regulated and are not part of the subsidized system. According to an estimate by the Ministry of Industry, Trade and Labour, in 2007 about 96,000 children under the age of 4 were enrolled in unlicensed and unregulated group settings. Lately, there has been intense debate regarding the quality of child care centers and the way to regulate them (Fichtelberg, 2008). Furthermore, beside day care centers, there are also Private Nanny services available; care for one or two children from birth to the age of three, either in the nanny's home or in the child's.

\subsection{Health}

122. Israel has a national universal health insurance system, with service free at the point of delivery and provided by non-governmental "Sick Funds" responsible for the delivery of health services to all residents of Israel. Yet a number of crucial health services, especially those for young children, are fully governmental.

123. Child development centers emphasise early childhood development. These centers, together with another group of development centers operated by local municipalities, are the primary service providers for identifying, monitoring and treating developmental concerns in children from birth to the age of nine. Until the age of three, the use of these services is unlimited, and referrals are made at the discretion of professionals. From age three, the services are limited to a certain number of treatments per year.

124. Mother and Well Baby Clinics (“Tipat Halav") - This almost 100-year-old preventive care service is operated by the Ministry of Health and local municipalities (70\% of the clinics) or by the "Sick Funds" (the remaining 30\%). With a network of clinics established in almost every neighbourhood in Israel, this service reaches out to families with young children to immunise children, promote the early identification of health and developmental problems, monitor community health problems, and encourage

\footnotetext{
${ }^{35}$ As in day care centers, the phenomenon of unlicensed Family Day Care Programs is also very common.
} 
and train parents to live healthy lives. In recent years, there have been ongoing (though as yet unsuccessful) efforts by the Ministry of Finance to privatise the operation of these clinics and outsource them fully to the "Sick Funds".

125. As in other domains, the role and presence of the public non-governmental agencies in the delivery of health services for young children in Israel is growing. First and foremost, this includes all the Sick Funds, which play a major role in the delivery and managing of health care for young children. In addition, almost all services for children with special needs are delivered by NGOs.

126. While relatively new, the presence and role of the private sector in the delivery of health services for young children is also on the rise. Private health insurance to complement the National Health Insurance scheme is becoming popular, especially as a means of receiving additional services beyond what National Health Insurance includes.

127. There is also a broad range of welfare services that provide for children who require out-of-home care. The goal of these services is to deal with multi-generational distress, to improve child-parent relations, and to assist children at risk and their families. These include: Multi-Purpose Day Care Centers, which are located in day care facilities under the auspices of the Ministry of Industry, Trade and Labour, and operate extre-curriculum programs for children as well as support groups for parents and parent-child activities. Care in the afternoon, usually provided within the kindergarten or school setting, becomes the responsibility of the Ministry of Industry, Trade and Labour, and includes: Clubs (Moadoniyot) and "Playrooms" for young children that provide an educational therapeutic setting for up to 24 children of ages 3 to 6. Children-at-risk can also attend this service after school hours. "Home Clubs" are small frameworks for up to six children, operating daily and usually located inside a private home and run by a mother. Parental Support Programs are operated by the Ministry of Welfare and Social Services in cooperation with NGOs to reach out to and support families with young children, especially at-risk children.

128. Emergency Shelters - A relatively new service has been developed in recent years to protect children at immediate risk. These shelters aim to give immediate protection to children who have been harmed by their family or their environment. Finally, there are Daily Foster Care and Foster Care and Boarding Schools and Centers.

\section{Discussion and Conclusion}

129. This section of the report seeks to examine the various factors that explain the differences in outcomes for children and the overall results of policies in various fields. It will draw together the findings and the discussions of issues presented in previous sections.

130. The findings presented in the report indicate that Israel has a relatively comprehensive welfare state and a greater proportion of children than in other welfare states. The previous sections of this report have described in detail the cash benefits, protective legislation, regulatory mechanisms and in-kind services intended to meet the needs of children and to enable their parents to reconcile work and family responsibilities. In addition, the report provides information about the socio-demographic status of the country's children.

131. An examination of children's status and outcome indicators reveals that in a number of crucial social, educational and health fields, the indicators for Israel are acceptable and on a par with those in other welfare states. This includes health indicators such as infant mortality rate and average life expectancy; education indicators such as enrolment rates among children aged 0 to 14; and risk indicators such as the level of adolescents' abuse of psychoactive substances. 
132. However, this is clearly not the case when we review other findings. In particular, the report underscores the relatively high incidence of child poverty in the Israeli welfare state and the very marked disparities between social groups and the children belonging to these groups. Clearly, poverty and economic and social exclusion are particularly concentrated among children within the Arab and the ultraorthodox Jewish communities.

133. The findings indicating a high incidence of child poverty in Israel are, at first glance, paradoxical. Not only does the Israeli welfare state have a comprehensive array of benefits and services for children and families, but the ethos that has dominated social policy thinking in Israel since its establishment in 1948 has included a commitment to children and their wellbeing (Ben-Arieh \& Gal, 1998). Over the decades since then, policy-makers have emphasised that child welfare is a major goal of the welfare state, and they have sought to reflect this commitment in the services and benefits adopted.

134. The consistently high level of child poverty in Israel indicates that this long-term effort to ensure the wellbeing of children has had, at the very best, only limited success. It would appear that the high incidence of child poverty in Israel, and its concentration among children in specific social and ethnic groups, is the consequence of a number of causes.

135. Data relating to the demographic structure of families in Israel clearly identifies family size as one specific factor contributing to child poverty, due to the need to distribute limited resources to a greater number of individuals. Consequently, poverty levels within large families are disproportionally high.

136. While less than a fifth of the country's families are large (four or more children), their number is nevertheless significant (166 185 families). Moreover, due to cultural norms and religious beliefs, these families are concentrated particularly within the Arab Muslim and ultra-orthodox Jewish communities.

137. A second demographic factor contributing to the high incidence of child poverty is immigration. The limited financial and human resources available to immigrant families, at least in the initial stages of their acculturation process, can lead to high levels of distress. Indeed, following the mass influx of immigrants from the former Soviet Union and Ethiopia during the late 1980s and early 1990s, data on immigrant families did indeed indicate higher poverty levels than among native Israelis. However, with the major drop in immigration levels and the absorption process and due to the small number of family members within most immigrant groups, poverty levels among immigrant families have dropped sharply.

138. A third demographic factor contributing to child poverty in Israel is the growth of single-parent families. This is a consequence of changing social norms (marriage breakdown and an increased divorce rate) but is also linked to the relatively high proportion of single-parent families among the immigrant population. While the proportion of single-parent families in Israel remains low compared to other welfare states, nearly a tenth of all children are in single-parent families, which have significantly higher poverty levels than do dual-parent households. This is clearly linked to the limited resources available to these families.

139. The resources available to families with children have a major impact on poverty levels. The labour market is the primary source of financial resources in society. A lack of access to the labour market due to unemployment, an inability to participate fully in the labour market, or limited returns on employment are all likely to contribute to high levels of poverty, and thus have a detrimental impact on the children in these families. This is particularly the case if alternative sources of income are limited and if the number of individuals dependent on income from the labour market in a given household is large. This is indicated by the high level of pre-transfer poverty among children (39.9\%) and the extremely high level of pre-transfer poverty among large families (56.5\% among families with four or more children). 
140. Data on labour market participation rates in Israel indicate that these rates are relatively low in comparison to other advanced market economies. While they have been growing over time, female labour market participation rates in Israel remain relatively low, and part-time employment is common. Low participation rates are particularly common among Arab women. By contrast, male labour market participation rates are particularly low among ultra-orthodox Jewish men. In 2007, labour market participation in the male ultra-orthodox population was estimated to be $36.9 \%$, compared to $67.7 \%$ among the remainder of the male Jewish population.

141. Data on wage levels in Israel indicate that there are very marked differences between population groups within the labour market and that it is characterised by a high degree of inequality. Moreover, wage levels are particularly low for employees within the unskilled or low-skilled sectors of the economy and are often below the official minimum wage (NII, 2008a).

142. The causes of low labour market participation and of these marked disparities are numerous and differ, to a certain degree, for various social groups. Clearly, limited human capital, physical or mental disabilities, difficulties in reconciling work and family, limited returns on employment, discrimination within the labour market and a lack of education and employment opportunities (in the case of the Arab community), and cultural and religious norms all contribute to these results.

143. Families with children in which there are one or no breadwinners are likely to be susceptible to poverty. A high level of poverty among single-parent and immigrant families is one consequence of this. Poverty among children in large families is another. The combination of large families and single breadwinners, or limited returns on employment in Arab Muslim and ultra-orthodox Jewish families results, not surprisingly, in a high concentration of poverty among children in these groups.

144. While child policy in itself cannot resolve the more widespread socio-economic inequalities in Israeli society, social policies that focus on families and children can provide alternative resources to combat poverty and deprivation and can offer responses to particular needs. A combination of services, benefits and legislation can enable parents to better balance family and work and thus participate in the labour market, while still ensuring that their children receive adequate care. Educational, health and personal social services are crucial to efforts to ensure that children can develop their human capital and enjoy opportunities to fully develop their capabilities and skills. Developing these capabilities is crucial to ensuring labour market participation and acceptable living standards as adults.

145. Despite the array of policies and services that seek to deal with the needs of children and their families, these policies have not been very effective in combating poverty among Israel's children. While cash benefits seek to provide a safety net for families that lack an adequate income to cover the additional expenses related to child-rearing, and services provided by the state (or regulated by it) offer wide access to education, health care and social service free of charge or at very reduced cost, the impact of this system on child poverty remains limited. Thus, for example, the influence of cash benefits on poverty levels among children reduces the incidence of child poverty by less than a fifth $(14.3 \%)$.

146. Changes in social policy in recent years also appear to have contributed to this result. A growing emphasis on other population groups within the social protection system and major cuts in cash benefits for children, such as child benefits, and for families (income support) have eroded the income of many families, particularly single-parent and large families. Furthermore, the ongoing privatisation and 
commodification of services, the weakness of state regulations and of its enforcement capacities ${ }^{36}$ has limited access to adequate services by families living in poverty.

147. Indeed, the actual "welfare package" of benefits, services and tax expenditures directed at families with children in Israel remains relatively limited and ultimately inadequate to deal with the needs of the country's child population. A recent cross-national comparative study found that Israel has a relatively simple and uni-dimensional package that is comprised primarily of non-means-tested child benefits (Gal \& Ben-Arieh, 2003). In comparison to other welfare states, Israel was ranked in the third quarter of nations, alongside Australia, Italy, the United States, the United Kingdom and Canada (see Bradshaw \& Fitch, 2002).

\section{Policy Recommendations}

148. On the basis of the data presented in this report and the concluding discussion, we offer the following policy recommendations. The goal of these policy recommendations is to contribute to a reduction in child poverty levels in Israel, to increase the wellbeing of the children, and to facilitate better work-family reconciliation. The recommendations are divided by domain of welfare state activity:

1. Cash transfers

a) Child Benefits should be maintained as non-means-tested and non-conditional benefits provided to all families with children below the age of 18. Income support benefits for families with children should provide families with an acceptable minimum standard of living. At the very least, this implies restoring these benefits to the level they were at the beginning of the current decade. An "additional needs" component should be included in the program for long-term beneficiaries. These changes should be adopted in parallel to extending the welfare-to-work program so that it encompasses all income support recipients.

b) Unemployment insurance is particularly limited in Israel. In order to provide effective protection for unemployed families with children, the qualification period for this program should be reduced to six months and the duration of payment lengthened so that it ranges from $6-12$ months. Payments can be tapered towards the end of this period.

c) The Negative income tax program should be extended to include all low-income working families with children. Take-up of the program should be improved by simplifying the applications procedure and the level of benefits increased. Alternatively, the state should consider raising the current minimum wage.

d) Maternity benefits should be extended to a period of six months after birth. Fathers should be encouraged to take up this benefit.

2. Childcare

\footnotetext{
${ }^{36}$ As already mentioned, recent studies indicate that the rights of many women workers, in general, and mothers in particular, are abused and that labour laws have only a minimal impact on their work conditions (Ajzenstadt, in press). Furthermore, the State Comptroller recently pointed to some major problems in the process of labour law enforcement, which is the responsibility of the Ministry of Industry, Trade and Labour (The State Comptroller, 2007). For further reading on the subject of labour law enforcement in Israel see: Davidov, 2005.
} 
a) The state should devote additional resources to establishing a wider infrastructure for childcare, in particular, to fund childcare facilities in the Arab sector.

b) More efficient regulatory mechanisms to ensure the quality of childcare and the ratio of carers-to-children in these institutions should be created, including clear-cut guidelines on the quality of childcare.

c) The State should enforce regulations and standards of care for any childcare setting with more than 2 children between the ages of 0 and 3 years.

d) Greater subsidies should be offered to parents in order to enhance access to childcare. The idea of a tax credit has been the subject of recent public debate. As this type of subsidy is accessible only to working parents and ignores parents whose income is so low that it is not taxed, we do not recommend it. The current quasi-market subsidy structure, in which the state directly finances the organisations operating the childcare centers, is an optimal solution. Nevertheless, this structure should be improved by increasing both the level of the subsidies and the availability of subsidised childcare centers. In addition, the subsidies should be structured so as to maintain choice and be culturally sensitive.

3. Labour Markets

a) A more effective system to enforce labour legislation is required. The current lack of regulation emboldens employers to ignore the law on minimum wages and genderrelevant protection.

b) Additional efforts to address inequalities in the labour market and enhance labour market participation are required, particularly in the case of Arab women and ultra-orthodox men. In addition to the transfer and legislation recommendations, these efforts should promote better access to training and education aimed at enhancing human capital.

1. Social Care

a) The state should develop a "basket" of social services to which each family with children are entitled and which is based on clear eligibility criteria and statutory funding.

b) The state should define the target population of at-risk children and develop a variety of services for these children that will be embedded in legislation and available to children in distress.

c) The level of funding and especially the ratio of professionals-to-children, and specifically to at-risk children, should revert to the level it was in the early 1980 s.

2. Health

a) The universal mother and baby well clinics (Tipat Halav) should be kept as a public service. Access to these services should be free of charge and available to all pregnant women and young parents and their babies.

b) The national health insurance system should be expanded to cover all children living in Israel regardless of their legal position (as stated in the UN Convention on the Rights of the Child). This expansion will hopefully deal both with the lack of effective national health coverage of Arab children in East Jerusalem and with the low take-up rates of the 
voluntary health care insurance aimed at the children of labour migrants. There is a need to initiate a national program to provide medicine for children free of cost (beyond the health insurance payments) and thus prevent socio-economic disparities in receiving medical services.

3. Education

a) The implementation of compulsory education for ages 3-5 and 15-17 should be expedited so as to include the entire country.

b) Alternative outcome indicators to those on learning achievements (such as on school climate) should be incorporated into the system.

c) Government spending in the Arab and the Jewish education systems should be equalised. This suggestion has general applicability, but has special relevance to children living in unrecognised Bedouin localities in the Negev region. 


\section{BIBLIOGRAPHY}

Ajzenstadt, M. (2010). Families, children and women in the Israeli state: 1880s -2008. In M. Ajzenstadt \& J. Gal (eds.), Children, Gender and Families in Mediterranean Welfare States. Springer

Ajzenstadt, M. \& Gal, J. (2001). Appearances can be deceptive: Gender in the Israeli welfare state. Social Politics, 8, 292-324.

Ajzenstadt, M. \& Laor, N. (in press). Labour market arrangements for working parents: Israel in a crossnational comparative perspective. The Hebrew University of Jerusalem (in Hebrew).

Asiskovitch, S., \& Shooshy, N. (2006). Healthy boundaries: Health insurance for labour migrants' children through a global perspective. A paper presented at the Minerva Centre for Human Rights conference, Jerusalem.

Bank of Israel (2008). Recent Economic developments, 122. Jerusalem: Bank of Israel.

Ben-Arieh, A. \& Gal, J. (1998). The paradox of child poverty in Israel. European Journal of Social Work, 1,347-359.

Benbenishty, R., Zeira, A., Astor, R. A. \& Koury-Kassabri, M. (2002). Maltreatment of primary school students by educational staff in Israel. Child Abuse \& Neglect, 26, 1291-1309.

Bradshaw, J. \& Fintch, N. (2002). A comparison of child benefit packages in 22 countries. DWP research report, No. 174. Leeds: CDS.

Central Bureau of Statistics (2009a). Family day: Families and households in Israel. Jerusalem.

Central Bureau of Statistics (2009b). Statistical abstract of Israel 2009. Jerusalem.

Central Bureau of Statistics (2008a). Infant mortality 1997-2004: Demographic and health characteristics. Jerusalem.

Central Bureau of Statistics (2008b). Labour force survey 2007. Jerusalem.

Central Bureau of Statistics (2007). Children in kindergartens and day-care centres 2004/2005. Jerusalem.

Davidov, G (2005). Enforcement problems in "informal" labour markets: A view fromIsrael. Comparative Labour Law and Policy Journal, 27, 3-25.

Doron, A. (2001). Social welfare policy in Israel: Developments in the 1980s and 1990s. In D. Nachmias \& G. Menachem (eds.), Public policy in Israel (pp. 158-180). London: Frank Cass.

Doron, A. \& Kramer, R. (1991). The welfare state in Israel. Boulder CO: Westview. 
Fichtelberg, O. (2008). Group frameworks for young children: Assessments for 2007.Ministry of Industry, Trade and Labour.

Gal, J. (1998). Categorical benefits in welfare states: Findings from Britain and Israel. International Social Security Review, 51, 73-102.

Gal, J. (2005). The rise and fall of unemployment insurance in Israel. International Social Security Review, 58, 107-116.

Gal, J. \& Bargal, D. (2002). Critical junctures, labour movements and the development of occupational welfare in Israel. Social Problems, 49, 432-454.

Gal, J. \& Ben-Arieh A. (2003). Income transfers and support for families with children in a comparative perspective. Social Security, 63, 69-96 .

Gottlieb, D. (2007). Poverty and labour market behaviour in the ultra-orthodoxultra-orthodox population in Israel. The Van-Leer Jerusalem Institute.

Gurovich, N. \& Cohen-Kastro, E. (2004). Ultra-orthodox Jews: Geographic distribution and demographic, social and economic characteristics of the ultra-orthodox Jewish population in Israel, 1996-2001. Jerusalem: Central Bureau of Statistics - Demography Sector.

Hibell B., Guttormsson U., Ahlströhm S., Balakireva O., Bjarnason T., Kokkevi A., \& Kraus L. (2009). The 2007 ESPAD Report: substance use among students in 35 European countries. Stockholm, Sweden.

Holler, R. \& Gal, J (in press). Subsidies for early childhood education and care: The Israeli model in a cross-national comparative perspective. The Hebrew University of Jerusalem.

Horev, T. \& Kop, Y. (2009). Israel's social services, 2008. Jerusalem: Taub Centre for Social Policy Studies in Israel.

Izraeli, D. N. (1992). Culture, policy and women in dual-earner families in Israel. In S. D. Lewis, N. Izraeli, \& H. Hootsmans (eds.), Dual-earner families: International perspectives. London: Sage.

Laor, N. \& Ben-Arieh, A. (in press). The regulation of early childhood education and care: A crossnational comparison and proposals for policy reform. The Hebrew University of Jerusalem.

Luxembourg Income Study (2009). LIS key figures. Retrieved April, 2009 from: http://www.lisproject.org.

Myers-JDC-Brookdale Institute (2000). Children with special needs: An assessment of needs and coverage by services. Jerusalem.

Ministry of Finance, State Revenues Administration (2008). Annual report, 2007.

National Insurance Institute (2008a). Annual survey 2007. Jerusalem.

National Insurance Institute (2008b). Poverty report: Poverty and social gaps in 2007. Jerusalem.

National Insurance Institute (2008c). Statistical quarterly. Jerusalem

OECD (2010). OECD reviews of labour market and social policies: Israel. Paris: OECD. 
OECD (2008). Statistical profile of Israel. Retrieved April, 2009 from: http://stats.oecd.org.

OECD (2007). Benefits and wages: OECD indicators. Paris: OECD.

Okun, B. S., Oliver, A. L. \& Khait-Marelly, O. (2007). The public sector, family structure and labour market behaviour: Jewish mothers in Israel. Work and Occupations, 34, 174-204.

Rosenhek, Z. (1999). The exclusionary logic of the welfare state: Palestinian citizens in the Israeli welfare state. International Sociology, 14, 195-215.

Schiff, M., \& Benbenishty, R. (2008). Adolescents' exposure to negative life events and substance use:

Risk and protective factors: A comparison between Israeli born adolescents and Former

Soviet Union adolescents. Israel Anti-Drug Authority

Sheffer, N. (1999). The Israeli government's policy in subsidizing daycare: Its implications for women's work outside the home. Jerusalem: Israel Women's Network.

Sikkuy (2008). The equality index of Jewish and Arab citizens in Israel: 2007. Jerusalem-Haifa.

Soen, D. (2002). School violence and its prevention in Israel. International Educational Journal, 3, 188205.

The State Comptroller (2007). Annual report 58/b. Jerusalem (in Hebrew).

Tzionit, Y., Berman, Z., \& Ben-Arie, A. (2009). The state of the child in Israel, 2008: A statistical abstract. Jerusalem: Israel National Council for the Child.

Tzionit, Y., Kimchi, M., \& Ben-Arie, A. (2008). The state of the child in Israel, 2007: A statistical abstract. Jerusalem: Israel National Council for the Child.

World Health Organizaton (2007). The challenge of obesity in the WHO European Region and the strategies for response. Retrieved July, 2009 from: http://www.euro.who.int/document/E90711

World Health Organization (2006). Estimates of child and adult mortality and life expectancy at birth by country. Retrieved April, 2009 from:

http://www.who.int/healthinfo/statistics/mortlifeexpectancy/en/index.html 


\section{APPENDIX 1}

\section{Legislation:}

Since the establishment of the State of Israel, a number of important laws regarding children have been enacted. These include:

The Compulsory Education Law (1949) - This law states that every child from the age of 5 to 14 is entitled to free school education. Recent legislative reform has changed the recipient ages to 3-17.

The Supervision of Boarding houses/Shelters Law (1965) - This law regulates the supervision of shelters. Its goal is to regulate and license external housing frameworks for the indigent, including children. There is currently a legislative proposal to regulate the supervision of infant and child care under the age of three and to ensure appropriate care even if the children remain in small housing frameworks with a minimum of three children.

The Stable Prices for Products and Services Decree (maximum price for day care and family day care) (2005) - This decree states a maximum monthly payment for day care and family day care which is updated annually. However, in practice, this decree is not enforced in private frameworks.

The School Supervision Law (1969) - This law applies to all educational frameworks (governmental and private) that include more than 10 children over the age of three. The law specifies the terms of supervision for the framework. Currently, the responsibility of reporting on the educational centre applies to the owner. Many owners avoid reporting and therefore operate illegally and without supervision.

Special Education Law (1988) - This law entitles children with disabilities, ages 3 to 21, to a free education suited to their needs. The law also stipulates that the state is responsible for providing this service.

The Safe Transportation for Children and Infants with Disabilities Law (1994) - This law stipulates that infants and children with disabilities are entitled to transportation from their home or nearby to their educational center and back according to their specific needs and disabilities

The Extended School Day and Enrichment Studies Law (1997) - The aim of this law is to provide equal educational opportunities to every child in Israel by increasing the amount of hours in school per day.

The Children at High Risk Law (Right to Day Care) (2000) - This law determines that a child at-risk has the right to day care and that the state must ensure the fulfilment of this right. The law was established in the year 2000, but was "frozen" for two years (until May 2003). Since 2003, the law has been implemented in 100 localities and gradually extended since then.

The Rehabilitative Day Care Center Law (2000) - This law is meant to ensure that every infant aged 1 to 3 who suffers from a disability or handicap is eligible for appropriate rehabilitation, therapy and education. 


\section{OECD SOCIAL, EMPLOYMENT AND MIGRATION WORKING PAPERS}

Most recent releases are:

No. 103 REFORMING POLICIES ON FOREIGN WORKERS IN ISRAEL Adriana Kemp

No. 102 LABOUR MARKET AND SOCIO-ECONOMIC OUTCOMES OF THE ARAB-ISRAELI POPULATION Jack Habib, Judith King, Asaf Ben Shoham, Abraham Wolde-Tsadick and Karen Lasky

No. 101 TRENDS IN SOUTH AFRICAN INCOME DISTRIBUTION AND POVERTY SINCE THE FALL OF APARTHEID

Murray Leibbrandt, Ingrid Woolard, Arden Finn and Jonathan Argent

No. 100 MINIMUM-INCOME BENEFITS IN OECD COUNTRIES: POLICY DESIGN, EFFECTIVENESS AND CHALLENGES

Herwig Immervoll (2009)

No. 99 HAPPINESS AND AGE CYCLES - RETURN TO START...? ON THE FUNCTIONAL RELATIONSHIP BETWEEN SUBJECTIVE WELL-BEING AND AGE Justina A.V. Fischer (2009)

No. 98 ACTIVATION POLICIES IN FINLAND

Nicola Duell, David Grubb and Shruti Singh (2009)

No. 97 CHILDREN OF IMMIGRANTS IN THE LABOUR MARKETS OF EU AND OECD COUNTRIES: AN OVERVIEW

Thomas Liebig and Sarah Widmaier (2009)

No. 96 INCOME DISTRIBUTION AND SUBJECTIVE HAPPINESS: A SURVEY Claudia Senik (2009)

No. 95 LOOKING INSIDE THE PERPETUAL-MOTION MACHINE: JOB AND WORKER FLOWS IN OECD COUNTRIES

Andrea Bassanini and Pascal Marianna (2009)

No. 94 JOBS FOR IMMIGRANTS: LABOUR MARKET INTEGRATION IN NORWAY Thomas Liebig (2009)

No. 93 THE WELFARE EFFECTS OF SOCIAL MOBILITY Justina A.V. Fischer (2009)

No. 92 HOW EXPENSIVE IS THE WELFARE STATE? GROSS AND NET INDICATORS IN THE OECD SOCIAL EXPENDITURE DATABASE (SOCX)

Willem Adema and Maxime Ladaique (2009)

No. 91 SHOULD PENSION SYSTEMS RECOGNISE "HAZARDOUS AND ARDUOUS WORK”? Asghar Zaidi and Edward Whitehouse (2009)

No. 90 GOING SEPARATE WAYS? SCHOOL-TO-WORK TRANSITIONS IN THE UNITED STATES AND EUROPE

Glenda Quintini and Thomas Manfredi (2009)

No. 89 LEGISLATION, COLLECTIVE BARGAINING AND ENFORCEMENT: UPDATING THE OECD EMPLOYMENT PROTECTION INDICATORS

Danielle Venn (2009)

No. 88 TOWARDS A FRAMEWORK FOR ASSESSING FAMILY POLICIES IN THE EU Henning Lohmann, Frauke H. Peter, Tine Rostgaard and C. Katharina Spiess (2009)

No. 87 INVESTMENT RISK: IMPACT ON RETIREMENT INCOMES AND GOVERNMENT BUDGETS Edward Whitehouse, Anna Cristina D’Addio and Andrew Reilly (2009)

Other series of working papers available from the OECD include: OECD HEALTH WORKING PAPERS 
DELSA/ELSA/WD/SEM(2010)4

\section{RECENT RELATED OECD PUBLICATIONS:}

JOBS FOR YOUTH: UNITED STATES (2009)

JOBS FOR YOUTH: POLAND (2009)

OECD EMPLOYMENT OUTLOOK: Tackling the Jobs Crisis (2009)

DOING BETTER FOR CHILDREN (2009)

SOCIETY AT A GLANCE - ASIA/PACIFIC EDITION (2009)

OECD REVIEWS OF LABOUR MARKET AND SOCIAL POLICIES: SLOVENIA (2009)

INTERNATIONAL MIGRATION OUTLOOK: SOPEMI (2009)

PENSIONS AT A GLANCE 2009: Retirement-Income Systems in OECD Countries (2009)

JOBS FOR YOUTH: FRANCE (2009)

SOCIETY AT A GLANCE 2009 - OECD Social Indicators (2009)

JOBS FOR YOUTH: AUSTRALIA (2009)

OECD REVIEWS OF LABOUR MARKET AND SOCIAL POLICIES: CHILE (2009)

PENSIONS AT A GLANCE - SPECIAL EDITION: ASIA/PACIFIC (2009)

SICKNESS, DISABILITY AND WORK: BREAKING THE BARRIERS (VOL. 3) - DENMARK, FINLAND, IRELAND AND THE NETHERLANDS (2008)

GROWING UNEQUAL? Income Distribution and Poverty in OECD Countries (2008)

JOBS FOR YOUTH: JAPAN (2008)

JOBS FOR YOUTH: NORWAY (2008)

JOBS FOR YOUTH: UNITED KINGDOM (2008)

JOBS FOR YOUTH: CANADA (2008)

JOBS FOR YOUTH: NEW ZEALAND (2008)

JOBS FOR YOUTH: NETHERLANDS (2008)

OECD LABOUR FORCE STATISTICS: 1987-2007 (2008)

JOBS FOR IMMIGRANTS (Vol.2): Labour Market Integration in Belgium, France, the Netherlands and Portugal (2008)

IMMIGRANT HEALTH WORKERS IN OECD COUNTRIES IN THE BROADER CONTEXT OF HIGHLY SKILLED MIGRATION (2008)

INTERNATIONAL MIGRATION OUTLOOK (2008)

OECD EMPLOYMENT OUTLOOK (2008)

OECD REVIEWS OF LABOUR MARKET AND SOCIAL POLICIES IN SERBIA (2008)

A PROFILE OF IMMIGRANT POPULATIONS IN THE $21^{\text {ST }}$ CENTURY (2008)

For a full list, consult the OECD On-Line Bookstore at www.oecd.org 